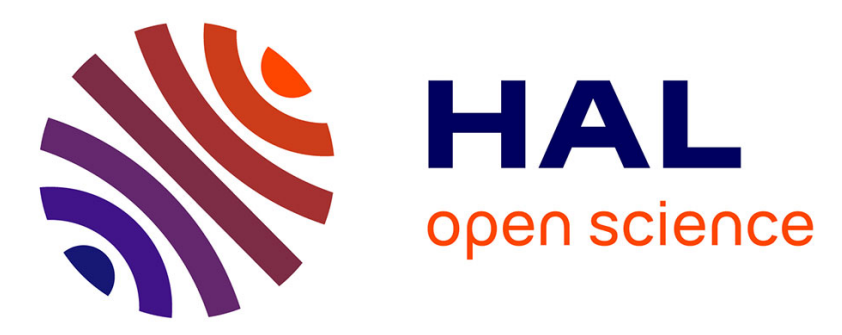

\title{
Relative Stereochemical Determination and Synthesis of the C1-C17 Fragment of a New Natural Polyketide
}

Etienne Fleury, Marie-Isabelle Lannou, Olivia Bistri, François Sautel, Georges

Massiot, Ange Pancrazi, Janick Ardisson

\section{- To cite this version:}

Etienne Fleury, Marie-Isabelle Lannou, Olivia Bistri, François Sautel, Georges Massiot, et al.. Relative Stereochemical Determination and Synthesis of the C1-C17 Fragment of a New Natural Polyketide. Journal of Organic Chemistry, 2009, 74 (18), pp.7034-7045. 10.1021/jo9012833 . hal-02371106

\section{HAL Id: hal-02371106 \\ https://hal.science/hal-02371106}

Submitted on 20 Oct 2021

HAL is a multi-disciplinary open access archive for the deposit and dissemination of scientific research documents, whether they are published or not. The documents may come from teaching and research institutions in France or abroad, or from public or private research centers.
L'archive ouverte pluridisciplinaire HAL, est destinée au dépôt et à la diffusion de documents scientifiques de niveau recherche, publiés ou non, émanant des établissements d'enseignement et de recherche français ou étrangers, des laboratoires publics ou privés. 


\title{
Relative Stereochemical Determination and Synthesis of the C1-C17 Fragment of a New Natural Polyketide
}

\author{
Etienne Fleury, ${ }^{\dagger}$ Marie-Isabelle Lannou, ${ }^{\dagger}$ Olivia Bistri, ${ }^{\dagger}$ François Sautel,, \\ Georges Massiot, ${ }^{\star}$ Ange Pancrazi, ${ }^{* \dagger}$ and Janick Ardisson* ${ }^{* \dagger}$ \\ ${ }^{\dagger}$ CNRS UMR 8638, Faculté de Pharmacie, Université Paris Descartes, 4 avenue de l'observatoire, 75270 \\ Paris cedex 06, France, and ${ }^{\star}$ CNRS/Pierre Fabre UMS 2597, Laboratoire Pierre Fabre, 3 rue des satellites, \\ BP 94244, 31402 Toulouse cedex 4, France
}

janick.ardisson@parisdescartes.fr; ange.pancrazi@parisdescartes.fr

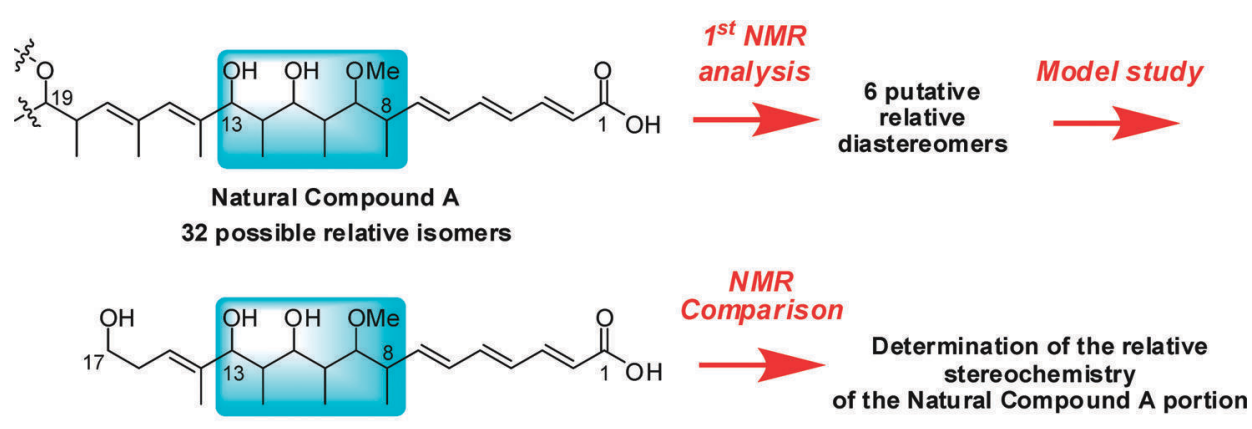

Synthes is of the 6 putative diastereomers

The challenging determination of the relative stereochemistry of a complex natural polyketide portion was achieved. After careful NMR analysis, a concise synthesis of a set of possible relative diastereomers (only 6 diastereomers out of the 32 initially envisioned) has been carried out using a common strategy based on enantioselective aldol reactions. With a high predictability, final NMR comparison established the relative stereochemistry of the $\mathrm{C} 1-\mathrm{C} 17$ fragment of this natural product.

\section{Introduction}

For more than a century, polyketides have been of great interest for the scientific community. Natural compounds of this family are produced by various organisms (such as bacteria, sponge invertebrates, fungi or plants) and exhibit a wide range of biological activity (antibiotic, antitumoral, antifungic, or immunomodulatory action) along with a great molecular complexity. ${ }^{1}$ Many of them include polypropio-

(1) (a) Yeung, K.-S.; Paterson, I. Chem. Rev. 2005, 105, 4237-4313. (b) Rohr, J. Angew. Chem., Int. Ed. 2000, 39, 2847-2849. (c) Paterson, I.; Mansuri, M. M. Tetrahedron 1985, 41, 3569-3624. (d) Omura, S. Macrolide Antibiotics; Academic Press Inc.: New York, 1984. 493.

(2) Davies-Coleman, M. T.; Garson, M. J. Nat. Prod. Rep. 1998, 15, 477-

(3) (a) Evans, D. A.; Clark, J. S.; Metternich, R.; Novack, V. J.; Sheppard, G. S. J. Am. Chem. Soc. 1990, 112, 866-868. (b) Evans, D. A.; Ng, H. P.; Clark, J. S.; Rieger, D. L. Tetrahedron 1992, 48, 2127-2142. (c) Paterson, I. Pure Appl. Chem. 1992, 64, 1821-1830. (d) Paterson, I.; Norcross, R. D.; Ward, R. A.; Romea, P.; Lister, M. A. J. Am. Chem. Soc. 1994, 116, 11287-11314. (e) For a recent review, see Schetter, B.; Mahrwald, R. Angew. Chem., Int. Ed. 2006, 45, 7506-7525. nate motifs, reflecting their common biosynthesis from propionates. $^{2}$

In general, the low abundance of these natural polyketides requires their total synthesis to deliver significant quantities of pure material for extensive testing. Moreover, in numerous cases, the stereochemistry of these natural products can only be established by stereocontrolled synthesis of putative structures, especially when analytical methods do not permit full assignment.

(4) (a) Brown, H.; Bhat, K. S.; Randad, R. S. J. Org. Chem. 1987, 52, 3701-3702. (b) Brown, H. C.; Bhat, K. S.; Randad, R. S. J. Org. Chem. 1989 , 54,1570-1576. (c) Roush, W. R.; Ando, K.; Powers, D. B.; Palkowitz, A. D.; Halterman, R. L. J. Am. Chem. Soc. 1990, 112, 6339-6348. (d) Roush, W. R.; Palkowitz, A. D.; Ando, K. J. Am. Chem. Soc. 1990, 112, 6348-6359. (e) Roush, W. R.; Grover, P. T. J. Org. Chem. 1995, 60, 3806-3813. (f) Panek, J. S.; Jain, N. F. J. Org. Chem. 1998, 63, 4572-4573. (g) Jain, N. F.; Takenaka, N.; Panek, J. S. J. Am. Chem. Soc. 1996, 118, 12475-12476. (h) BouzBouz, S.; Cossy, J. Org. Lett. 2001, 3, 3995-3998. (i) BouzBouz, S.; Cossy, J. Org. Lett. 2003, 5, 3029-3031. (j) Hoppe, D. Angew. Chem., Int. Ed. Engl. 1984, 23, 932-948. (k) de Lemos, E.; Porée, F.-H.; Bourin, A.; Barbion, J.; Agouridas, E.; Lannou, M.-I.; Commerçon, A.; Betzer, J.-F.; Pancrazi, A.; Ardisson, J. Chem.-Eur. J. 2008, 14, 11092-11112. 
<smiles>COC(O)C(C)C(C)C(C)C(C)/C(C)=C/C=C/C=C/C=C(\C)C(C)OC(=O)O</smiles>

Natural Compound A

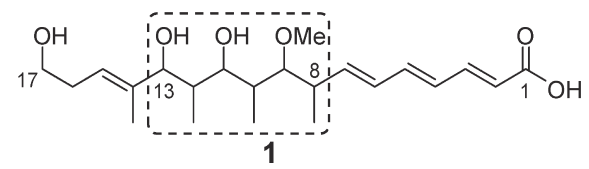

FIGURE 1. Structure of natural product $\mathbf{A}$ and model compound $\mathbf{1}$.

Elaboration of these polypropionates is challenging, considering the number of contiguous stereogenic centers. Therefore, numerous stereocontrolled approaches (such as aldol $^{3}$ and allylation/crotylation ${ }^{4}$ reactions) have been developed in the past three decades.

In this context, natural compound $\mathbf{A}$, a complex polyketide recently isolated by Pierre Fabre laboratories in association with IRD (Institut de Recherche pour le Développement), has been subjected to extensive work in our group (Figure 1). ${ }^{5}$ Its full structure elucidation is still under investigation, but the planar structure of the $\mathrm{C} 1-\mathrm{C} 19$ region was well-characterized as a three-propionate subunit (hexad) bordered with polyunsaturated chains. However, the stereochemical information was limited since the very low extraction yield prevented from any derivatization or degradation. The relative configurations of the stereogenic centers in the acyclic $\mathrm{C} 8-\mathrm{C} 13$ subunit were therefore not assigned (32 possible relative diastereomers). To solve this problem, a model compound 1, close enough to the natural compound to enable NMR comparison, was selected for synthesis (Figure 1). ${ }^{6}$

An extension of Kishi's NMR database method based on a statistical approach was first considered. ${ }^{7}$ However, the C9 methyl ether led to internal perturbations that could not be circumvented. Fortunately, a careful NMR data analysis provided an interesting indication. A surprisingly low ${ }^{13} \mathrm{C}$ NMR chemical shift ( $\delta=7.6 \mathrm{ppm})$ was noticed for the sole C12 methyl group and this characteristic value is consistent with a $s y n-s y n$ stereotriad, whether substituted or not. ${ }^{8}$ Consequently, the $\mathrm{C} 11-\mathrm{C} 13$ motif was assigned as a

(5) The $\mathrm{C} 1-\mathrm{C} 19$ portion represented in Figure 1 features approximatively half of the actual natural molecule.

(6) The relevant choice of a vinyl C14-C15 motif instead of the C14-C17 diene (like in the natural compound $\mathbf{A}$ ) was proved by preliminary NMR studies: no significant NMR differences were observed for the C8-C13 sequence between the two products 28a and 29a shown below (see Supporting Information for synthesis and NMR data of these two compounds).

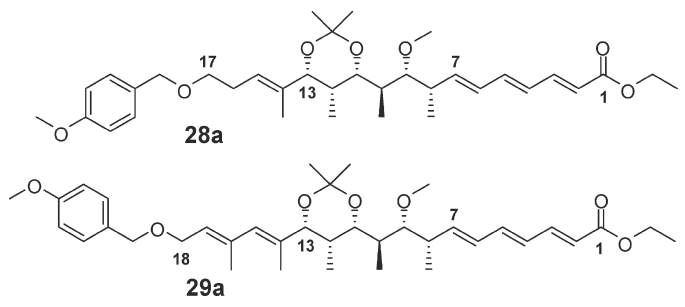

(7) (a) Fleury, E.; Lannou, M.-I.; Bistri, O.; Sautel, F.; Massiot, G.; Pancrazi, A.; Ardisson, J. Eur. J. Org. Chem. 2009, in press. (b) Kobayashi, Y.; Lee, J.; Tezuka, K.; Kishi, Y. Org. Lett. 1999, 1, 2177-2180. (c) Lee, J.; Kobayashi, Y.; Tezuka, K.; Kishi, Y. Org. Lett. 1999, 1, 2181-2184. (d) Kobayashi, Y.; Tan, C.-H.; Kishi, Y. J. Am. Chem. Soc. 2001, 123, 2076-2078.

(8) Hoffmann, R. W.; Weidmann, U. Chem. Ber. 1985, 118, 3980-3992. syn-syn stereotriad, and the C9-C11 motif as a syn-anti, anti-syn, or anti-anti stereotriad.

As a result of these considerations, only 6 relative diastereomers $(\mathbf{1 a}-\mathbf{f})$ out of the 32 initially envisioned could potentially correspond to natural product A (Figure 2). We set out to synthesize these 6 compounds $(\mathbf{1 a}-\mathbf{f})$ to determine the correct relative stereochemistry of the natural product.

\section{Results and Discussion}

As outlined in Scheme 1, the deconvolution of target $\mathbf{1}$ into three fragments $\mathbf{2}, \mathbf{3}$, and $\mathbf{4}$ has been envisaged.

Noteworthy, all the required stereovariations will occur in the central fragment 4. This subunit presents five of the six contiguous stereogenic centers of the C8-C13 hexad, the $\mathrm{C} 13$ carbonyl group being subsequently reduced. The final set up of the adjacent unsaturations will be achieved through a nucleophilic addition and a HornerWadsworth-Emmons olefination (Scheme 1).

Phosphonate $\mathbf{2}$ was readily accessible from sorbic acid $\mathbf{5}$ in three steps. The carboxylic acid function was protected as a trimethylsilylethyl ester. ${ }^{9}$ Indeed, a fluorine-cleavable protecting group proved to be necessary at this position since classical saponification methods ${ }^{10}$ of the corresponding ethyl ether failed to regenerate the acid in advanced stages of the synthesis. A cross metathesis/Arbuzov sequence developed by Cossy ${ }^{11}$ was then applied to 6 to yield phosphonate 2 with a high selectivity $(95 \%$ de, estimated by NMR analysis of the crude reaction mixture; Scheme 2).

Compound $\mathbf{3}$ was efficiently prepared, with a total selectivity, from commercial 2,3-dihydrofuran 7 using a cuprate transposition developed by Kocienski ${ }^{12}$ and recently applied in total synthesis in our laboratory. ${ }^{4 k, 13}$ The resulting vinyl tin species 8 was protected at the $\mathrm{C} 17$ position as a tert-butyldiphenylsilyl ether and $\mathrm{Sn} / \mathrm{Br}$ or $\mathrm{Sn} / \mathrm{I}$ exchange step was performed to lead to vinyl bromide $\mathbf{3 a}$ or vinyl iodide $\mathbf{3 b}$ (Scheme 3).

The central fragment $\mathbf{4}$ features the polypropionate pattern of $\mathbf{1}$ and therefore constitutes the portion where the stereovariation must take place to access all diastereomers $\mathbf{4 a}-\mathbf{f}$ (Figure 3) and, consequently, 1a-f. We designed a straightforward strategy that could provide the six isomers using common intermediates and featuring a minimum number of steps.

Stereocontrolled installation of the $\mathrm{C} 11-\mathrm{C} 12$ and $\mathrm{C} 9-\mathrm{C} 10$ hydroxy-methyl patterns would arise from iterative boronmediated aldol reactions, involving aldehydes 9 and $\mathbf{1 0}$, respectively. The $\mathrm{C} 8$ stereocenter would derive from Roche ester 11, commercially available in its $(R)$ or $(S)$ configuration (Scheme 4).

(9) Roush, W. R.; Blizzard, T. A. J. Org. Chem. 1984, 49, 1772-1783.

(10) Dockendorff, C.; Sahli, S.; Olsen, M.; Milhau, L.; Lautens, M. J. Am. Chem. Soc. 2005, 127, 15028-15029.

(11) (a) Amans, D.; Cossy, J. Angew. Chem., Int. Ed. 2006, 45, 5870-5874. (b) Ferrié, L.; Amans, D.; Reymond, S.; Bellosta, V.; Capdevielle, P.; Cossy, J. J. Organomet. Chem. 2006, 691, 5456-5465. (c) Hicks, J. D.; Flamme, E. M.; Roush, W. R. Org. Lett. 2005, 7, 5509-5512. (d) Schöning, K.-U.; Wittenberg, R.; Kirschning, A. Synlett 1999, 1624-1626.

(12) (a) Kocienski, P. Wadman, S.; Cooper, K. J. Am. Chem Soc. 1989 111, 2363-2365. (b) Kocienski, P.; Barber, C. Pure Appl. Chem. 1990, 62, 1933-1940. (c) Le Ménez, P.; Fargeas, V.; Berque, I.; Poisson, J.; Ardisson, J.; Lallemand, J.-Y.; Pancrazi, A. J. Org. Chem. 1995, 60, 3592-3599.

(d) Fargeas, V.; Le Ménez, P.; Berque, I.; Ardisson, J.; Pancrazi, A. Tetrahedron 1996, 52, 6613-6634.

(13) de Lemos, E.; Porée, F.-H.; Commerçon, A.; Betzer, J.-F.; Pancrazi, A.; Ardisson, J. Angew. Chem., Int. Ed. 2007, 46, 1917-1921. 

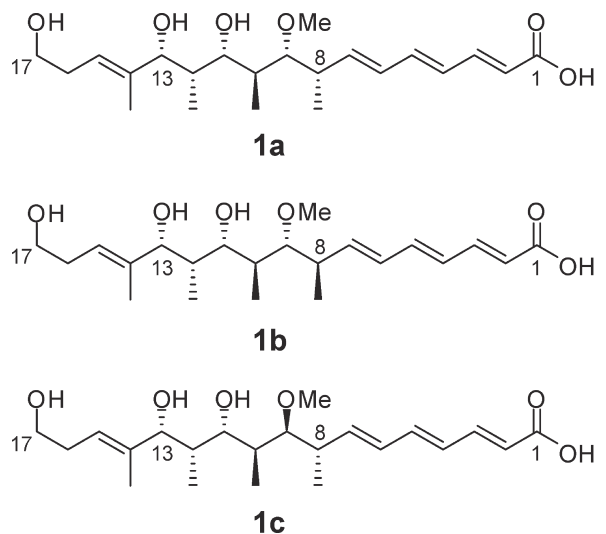

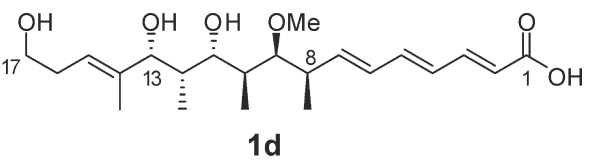<smiles>COC(C(C)[C@@H](C)/C=C/C=C/C=C/C(=O)O)C(C)[C@H](C)[C@@H](O)/C(C)=C/CC(O)[In]</smiles>

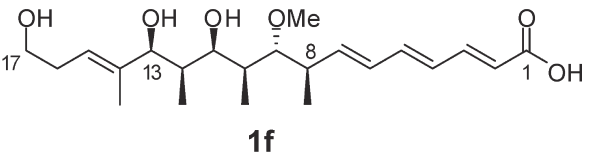

FIGURE 2. Structure of the six putative relative diasteromers $\mathbf{1 a}-\mathbf{f}$ corresponding to natural product $\mathbf{A}$.

\section{SCHEME 1. Retrosynthetic Analysis of Target Compound 1}

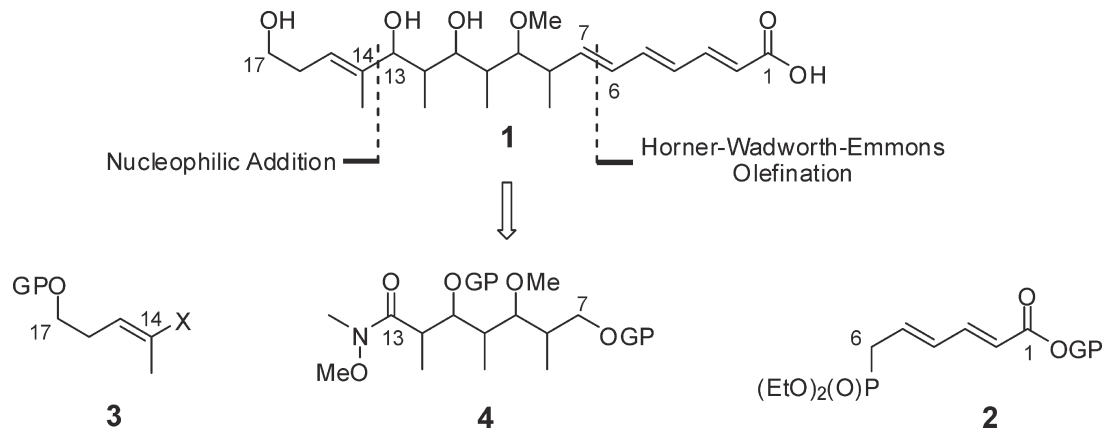

SCHEME 2. Synthesis of Fragment $2^{a}$

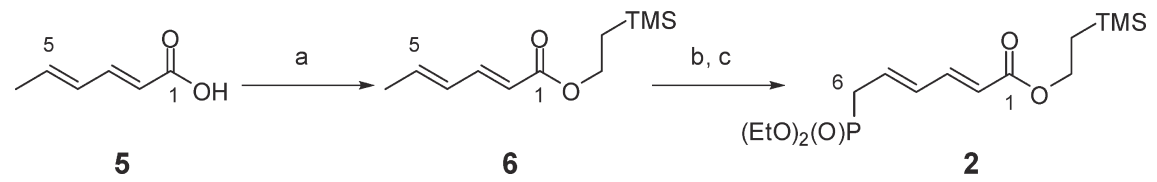

${ }^{a}$ Reagents and conditions: (a) TMSCH${ }_{2} \mathrm{CH}_{2} \mathrm{OH}, \mathrm{PPh}_{3}$, DIAD, THF, $0{ }^{\circ} \mathrm{C} \rightarrow$ r.t., 18 h, $83 \%$; (b) allyl bromide, Grubbs $-\mathrm{Hoveyda}$ second generation catalyst $3 \mathrm{~mol} \%, \mathrm{CH}_{2} \mathrm{Cl}_{2}$, r.t., $24 \mathrm{~h}, 62 \%$; (c) $\mathrm{P}(\mathrm{OEt})_{3}, 120^{\circ} \mathrm{C}, 1 \mathrm{~h}, 96 \%$.

SCHEME 3. Synthesis of Fragment $3^{a}$

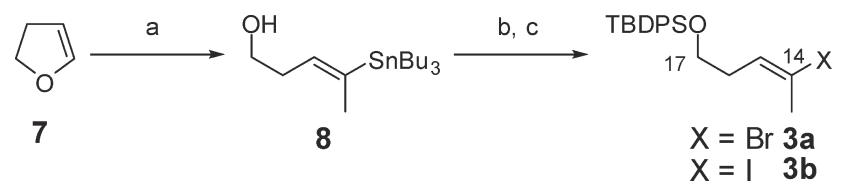

${ }^{a}$ Reagents and conditions: (a) (i) $t$-BuLi, THF, $-78^{\circ} \mathrm{C} \rightarrow 0{ }^{\circ} \mathrm{C}, 50 \mathrm{~min}$, (ii) $\left(\mathrm{Bu}_{3} \mathrm{Sn}\right)_{2} \mathrm{CuLi} \cdot \mathrm{LiCN}, \mathrm{Et}_{2} \mathrm{O},-78^{\circ} \mathrm{C} \rightarrow 0-5^{\circ} \mathrm{C}, 90 \mathrm{~min}$, (iii) $\mathrm{MeI},-30^{\circ} \mathrm{C} \rightarrow$ r.t., 5 h, $92 \%$; (b) TBDPSCl, imidazole, DMF, r.t., 90 min, $99 \%$; (c) (i) for 3a: NBS, $\mathrm{CH}_{2} \mathrm{Cl}_{2}, 0{ }^{\circ} \mathrm{C}, 45 \mathrm{~min}$, quant., (ii) for $3 \mathbf{b}: \mathrm{I}_{2}, \mathrm{CH}_{2} \mathrm{Cl}_{2}, 0{ }^{\circ} \mathrm{C}$, quant.

The first goal was to synthesize aldehydes $\mathbf{9 a}-\mathbf{d}$. To this aim, Paterson's boron-mediated aldol reaction turned out to be the most appropriate, because all of the four

(14) (a) Paterson, I. Synthesis 1998, 639-652. (b) Goodman, J. M.; Paterson, I. Tetrahedron Lett. 1992, 33, 7223-7226. (c) Paterson, I.; Wallace, D. J.; Velázquez, S. M. Tetrahedron Lett. 1994, 35, 9083-9086. (d) Paterson, I.; Wallace, D. J. Tetrahedron Lett. 1994, 35, 9087-9090. (e) Paterson, I.; Wallace, D. J. Tetrahedron Lett. 1994, 35, 9477-9480. (f) Paterson, I.; Chen, D. Y.-K.; Acena, J. L.; Franklin, A. S. Org. Lett. 2000, 2, 1513-1516. (g) Paterson, I.; Collett, L. A. Tetrahedron Lett. 2001, 42, 1187-1191. (h) Crossman, J. S.; Perkins, M. V. J. Org. Chem. 2006, 71, 117-124.

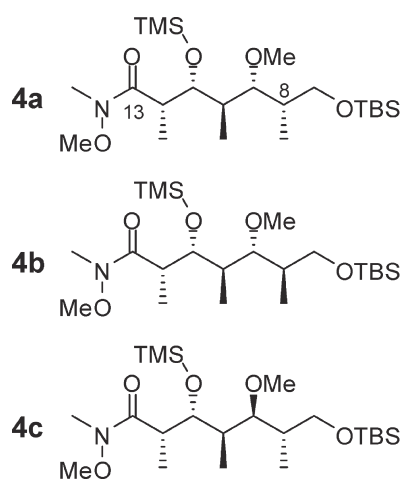

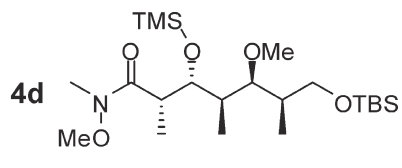<smiles>CO[C@@H]([C@@H](C)[C@@H](C)C[OH2+])[C@@H](C)[C@@H](OC)C(=O)N(C)OC</smiles>

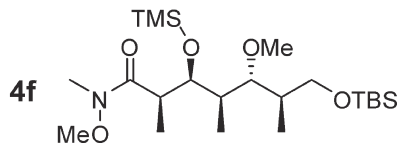

FIGURE 3. Structure of the six diastereomers $\mathbf{4 a}-\mathbf{f}$.

possible relative configurations of the $\mathrm{C} 8-\mathrm{C} 10$ stereotriad were accessible from only two aldehydes $(\boldsymbol{S})-\mathbf{1 0}$ and $(\boldsymbol{R}) \mathbf{- 1 0}$ and two known ketones $\mathbf{1 2}$ and $\mathbf{1 3}$ derived from ethyl (S)-lactate $\mathbf{1 4}$ (Scheme 5). ${ }^{14}$ Noteworthy, Paterson's boronmediated aldol reaction leads to the $E$ - or $Z$-enolate formation and consequently to the anti or syn aldol product 
SCHEME 4. Retrosynthetic Analysis of Fragment 4

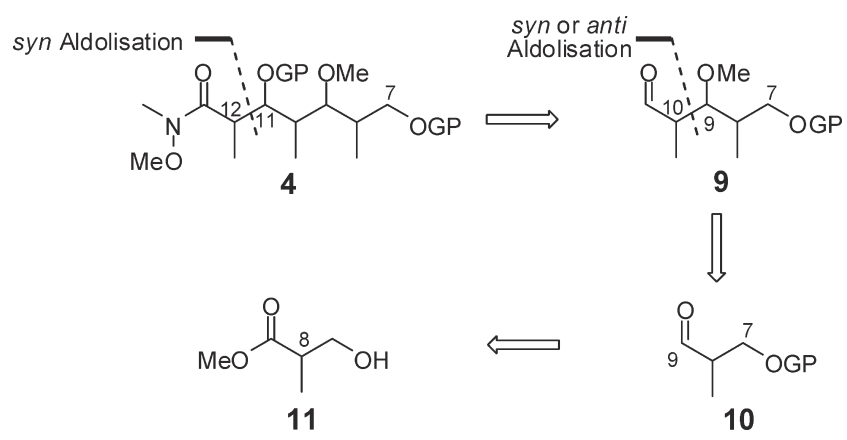

$\mathbf{1 5 a}-\mathbf{d}$ according to the hydroxyl protecting group (Bz or $\mathrm{Bn}$ ) of the starting ketones (12 or 13) and the enolization conditions.

Commercially available $(S)$-Roche ester $(\boldsymbol{S})$-11 was converted into aldehyde $(\boldsymbol{S}) \mathbf{- 1 0}$ by silylation of the C7 alcohol function, ester reduction and subsequent Swern oxidation of the C9 alcohol. ${ }^{4 \mathrm{c}}$ This aldehyde was then engaged in a substrate-controlled aldol coupling with the $E$-dicyclohexylboroenolate derived from $\alpha$-chiral ketone 12 to give the anti aldol product 15a with an excellent diastereoselectivity $(>95 \%$ de, estimated by NMR; Scheme 6). ${ }^{15}$

The C9 hydroxyl group of the resulting $\alpha$-keto alcohol 15a was subsequently methylated to provide compound 16a. The most efficient method consisted in the use of methyl trifluoromethanesulfonate with 2,6-di-tert-butyl-4-methylpyridine in refluxing dichloromethane. ${ }^{16}$ The reduction of both ketone and ester functionalities with lithium borohydride led to the corresponding diol, which was then cleaved by treatment with sodium periodate to yield aldehyde $\mathbf{9 a}$.

Synthesis of diastereomer $\mathbf{9 b}$ was performed in an identical manner, starting from $(R)$-Roche ester $(\boldsymbol{R})$-11 (Scheme 6). As before, the aldol reaction was achieved with a high diastereoselectivity.

Finally, for the synthesis of aldehyde 9c, the aldol reaction starting from $\alpha$-chiral ketone $\mathbf{1 3}$ generated the syn aldol product 15c (over 90\% de, estimated by NMR). After reduction of the ketone, the benzyl ether was cleaved by hydrogenolysis and subsequent oxidative cleavage with sodium periodate afforded aldehyde 9c. Synthesis of diastereomer 9d was performed in an identical manner (similar de was obtained), starting from $(\boldsymbol{R})-\mathbf{1 1}$ (Scheme 7).

Having the four possible relative diastereomers of the C7-C11 segment in hand, the synthesis of the six diastereomers $1 \mathbf{a}-\mathbf{f}$ was now possible through the setting up of the syn $\mathrm{C} 11-\mathrm{C} 12$ hydroxy-methyl core. First studies showed that Paterson's boron-mediated aldol reaction failed to give

(15) Aldol product 15a was already described, see (a) Paterson, I.; Florence, G. J.; Gerlach, K.; Scott, J. P.; Sereinig, N. J. Am. Chem. Soc. 2001, 123, 9535-9544. (b) Paterson, I.; Florence, G. J.; Gerlach, K.; Scott, J. P. Angew. Chem., Int. Ed. 2000, 39, 377-380. The stereochemistry assignment of other aldol products $\mathbf{1 5}$ was achieved through NOESY experiments of corresponding $\delta$-lactols $\mathbf{3 0}$ generated by cleavage of the silyl ether (see Solsona, J. G.; Romea, P.; Urpi, F. Tetrahedron Lett. 2005, 45, 5379-5382 and Supporting Information).

(16) Nakamura, R.; Tanino, K.; Miyashita, M. Org. Lett. 2003, 5, 35833586

(17) Organ, M. G.; Bilokin, Y. V.; Bratovanov, S. J. Org. Chem. 2002, 67, $5176-5183$ the expected aldol product. Fortunately, Evans aldol reaction, starting from $(\boldsymbol{S})-\mathbf{1 7},{ }^{17}$ successfully led to $\mathbf{1 8 a}$ (with over $95 \%$ de, estimated by NMR). ${ }^{18}$ After conversion of the oxazolidine moiety into a Weinreb amide functionality, ${ }^{19}$ the $\mathrm{C} 11$ alcohol was protected as a trimethylsilyl ether 4a.

This synthetic pathway was performed in an identical manner to afford diastereomers $\mathbf{4 b} \mathbf{- f}$, with similar selectivities (Scheme 8).

The synthesis of the six diastereomers $1 \mathbf{1}-\mathbf{f}$ was now possible through the coupling of fragments $\mathbf{2}$ and $\mathbf{3}$ with $\mathbf{4 a}-\mathbf{f}$ (Scheme 9).

Vinyl bromide 3a was treated with tert-butyllithium to generate the corresponding lithiated species, which could successfully be coupled to Weinreb amide $\mathbf{4 a} .{ }^{20}$ Surprisingly, we found that lithiation of the vinyl iodide $\mathbf{3 b}$ only led to the degradation of amide $\mathbf{4 a}$.

The $\mathrm{C} 11$ alcohol function was then deprotected and the C13 stereocenter was set up through a 1,3 diastereoselective reduction. The best result was obtained with zinc borohydride, and the $s y n-\operatorname{syn} \mathrm{C} 11-\mathrm{C} 12-\mathrm{C} 13$ stereotriad of 19a was generated in $91 \%$ yield and high diastereoselectivity (over $90 \%$ de, NMR estimation). ${ }^{21}$ The $\mathrm{C} 7$ primary alcohol function was then deprotected and the corresponding triol was treated with triethylsilyl trifluoromethanesulfonate in the presence of 2,6-lutidine. Differentiation between the triethylsilyl ethers was achieved by selective oxidation of the protected primary alcohol function into

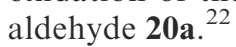

This aldehyde was further involved in a HornerWadsworth-Emmons olefination ${ }^{23}$ with phosphonate $\mathbf{1}$ to generate the $\mathrm{C} 6-\mathrm{C} 7$ double bond with over 95:5 $E$ stereoselectivity ( ${ }^{1} \mathrm{H}$ NMR analysis). Final deprotection was performed with tris(dimethylamino)sulfonium difluorotrimethylsilicate (TAS-F) to afford acid $\mathbf{1 a}{ }^{24}$

Finally, the five other diastereomers $\mathbf{1 b}-\mathbf{f}$ were synthesized, following the same sequence as depicted in Scheme 9 .

\section{NMR Comparison}

A direct comparison between natural product $\mathbf{A}$ and the six synthesized diastereomers $\mathbf{1 a}-\mathbf{f}$ was performed. Concerning

(18) Kangani, C. O.; Brückner, A. M.; Curran, D. P. Org. Lett. 2005, 7 , 379-382.

(19) Nicolaou, K. C.; Fylaktakidou, K. C.; Monenschein, H.; Li, Y.; Weyershausen, B.; Mitchell, H. J.; Wei, H.-X.; Guntupalli, P.; Hepworth, D.; Sugita, K. J. Am. Chem. Soc. 2003, 125, 15433-15442.

(20) (a) Raimundo, B. C.; Heathcock, C. H. Org. Lett. 2000, 2, 27-28. (b) Marumoto, S.; Kogen, H.; Naruto, S. Tetrahedron 1999, 55, 7145-7156. (c) Meyer, S. D.; Miwa, T.; Nakatsuka, M.; Schreiber, S. L. J. Org. Chem. 1992, 57, 5058-5060. (d) Hale, M. R.; Hoveyda, A. H. J. Org. Chem. 1992, 57, 1643-1645. (e) Schuppan, J.; Ziemer, B.; Koert, U. Tetrahedron Lett. 2000, $41,621-624$.

(21) This diol 19a was converted into the corresponding acetonide compound 28a (see Supporting Information). ${ }^{13} \mathrm{C}$ NMR analysis according to the Rychnovsky method confirmed the presence of a C11-C12-C13 synsyn relationship.

(22) (a) Rodríguez, A.; Nomen, M.; Spur, B. W.; Godfroid, J. J. Tetrahedron Lett. 1999, 40, 5161-5164. (b) Rodríguez, A.; Nomen, M.; Spur, B. W.; Godfroid, J. J.; Lee, T. H. Tetrahedron 2001, 57, 25-37. (c) Zanardi, F.; Battistini, L.; Marzocchi, L.; Acquotti, D.; Rassu, G.; Pinna, L.; Auzzas, L.; Zambrano, V.; Casiraghi, G. Eur. J. Org. Chem. 2002, 1956-1964. (d) Hübner, J.; Liebscher, J.; Pätzel, M. Tetrahedron 2002, 58, 10485-10500.

(23) (a) Evans, D. A.; Connell, B. T. J. Am. Chem. Soc. 2003, 125, 1089910905. (b) Nicolaou, K. C.; Daines, R. A.; Chakraborty, T. K.; Ogawa, Y. J. Am. Chem. Soc. 1988, 110, 4685-4696.

(24) For all this sequence, the choice of hydroxyl and acid protecting groups was imposed by problems of selectivity and stability of the different synthetic intermediates. 
SCHEME 5. Retrosynthetic Analysis of Aldehydes 9a-d
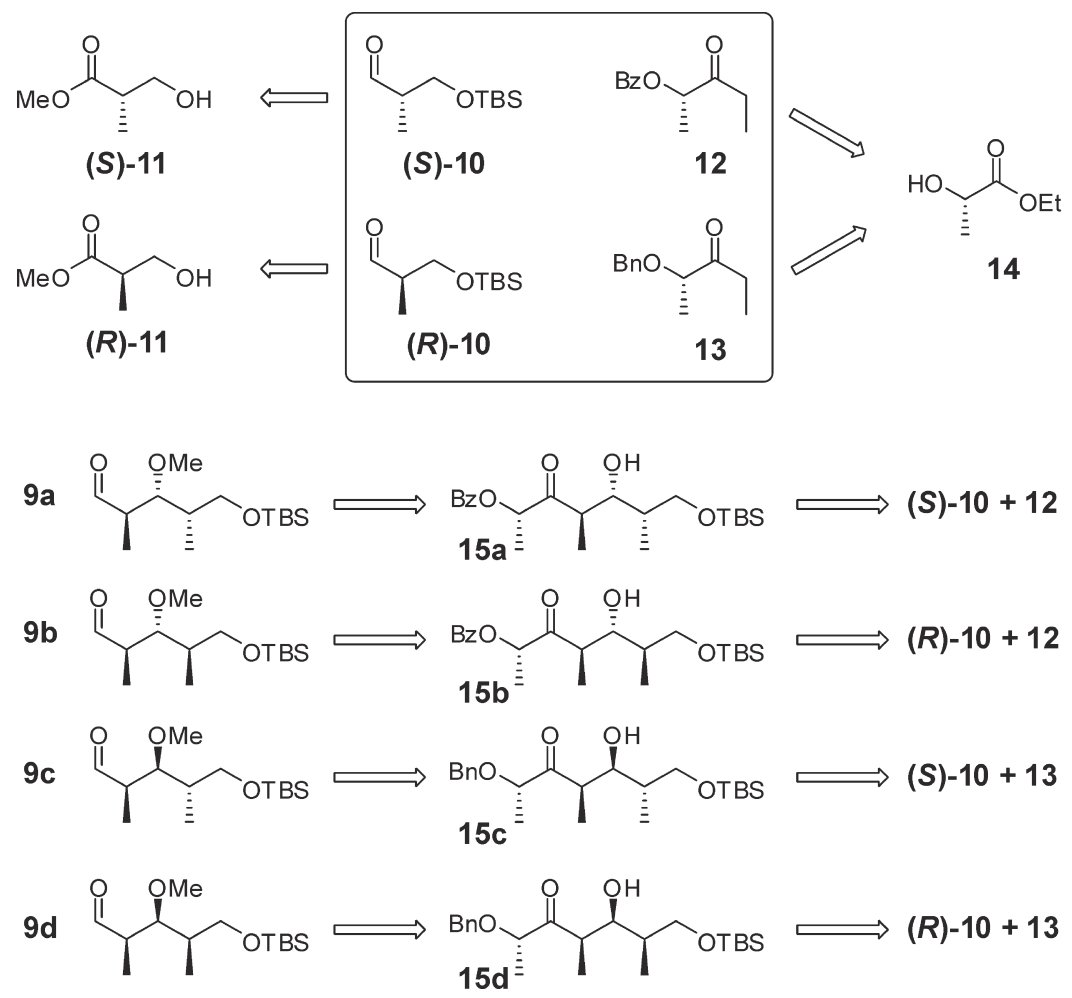

SCHEME 6. Synthesis of Aldehydes 9a and 9b
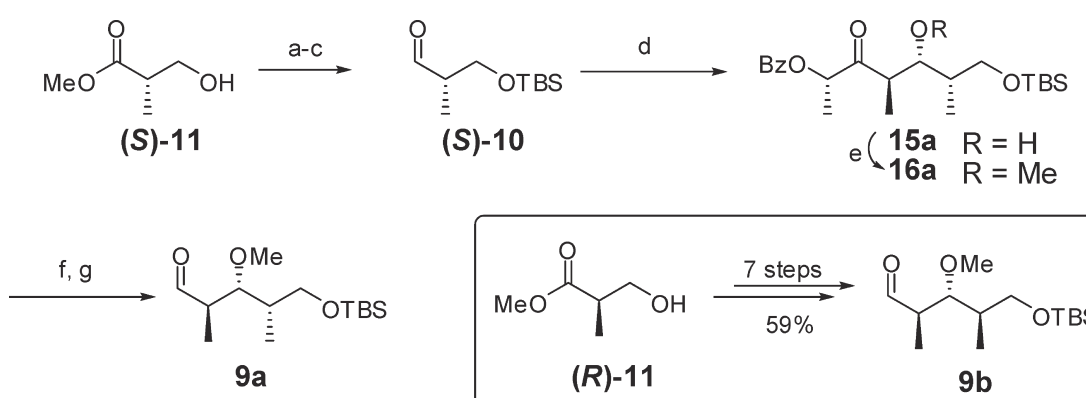

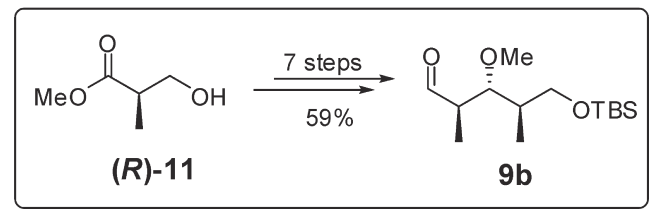

${ }^{a}$ Reagents and conditions: (a) TBSCl, imidazole, DMF, r.t., $18 \mathrm{~h}$; (b) DIBAL-H, $\mathrm{CH}_{2} \mathrm{Cl}_{2},-40{ }^{\circ} \mathrm{C} \rightarrow-20{ }^{\circ} \mathrm{C}, 3 \mathrm{~h}, 98 \%$ over 2 steps; (c) (i) $(\mathrm{COCl})_{2}, \mathrm{DMSO}, \mathrm{CH}_{2} \mathrm{Cl}_{2},-55^{\circ} \mathrm{C}, 1 \mathrm{~h}$, (ii) $\mathrm{Et}_{3} \mathrm{~N}$, r.t., $1 \mathrm{~h}, 100 \%$; (d) (i) $12, \mathrm{ClB}(\mathrm{Cy})_{2}, \mathrm{Me}_{2} \mathrm{NEt}, \mathrm{Et}_{2} \mathrm{O}, 0^{\circ} \mathrm{C}, 2 \mathrm{~h},\left(\right.$ ii) $(\mathrm{S})-10,-78^{\circ} \mathrm{C} \rightarrow-25^{\circ} \mathrm{C}$, $16 \mathrm{~h}, 98 \%$; (e) MeOTf, DTBMP, $\mathrm{CH}_{2} \mathrm{Cl}_{2}, 45^{\circ} \mathrm{C}, 24 \mathrm{~h}, 76 \%$; (f) $\mathrm{LiBH}_{4}, \mathrm{THF},-78{ }^{\circ} \mathrm{C} \rightarrow$ r.t., $16 \mathrm{~h}$; (g) $\mathrm{NaIO}_{4}, \mathrm{MeOH}$, r.t., $20 \mathrm{~min}, 84 \%$ over two steps.

\section{SCHEME 7. Synthesis of Aldehydes $9 \mathrm{c}$ and $9 \mathrm{~d}^{a}$}

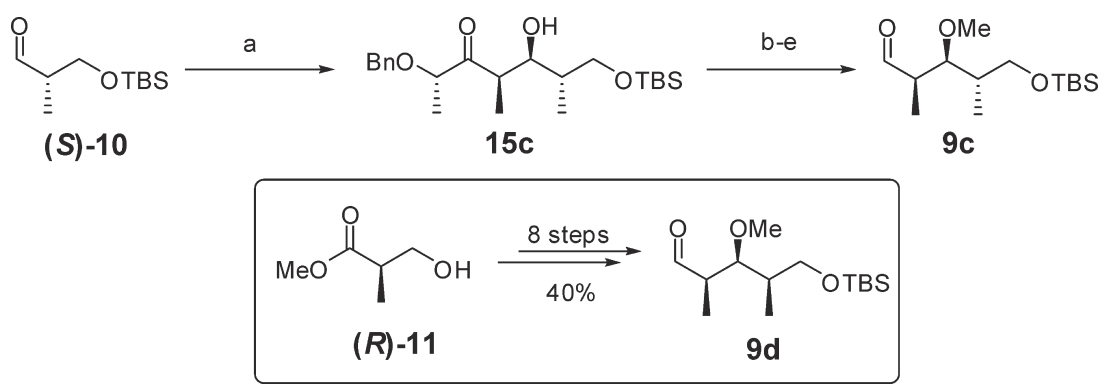

${ }^{a}$ Reagents and conditions: (a) (i) $13, \mathrm{ClB}(\mathrm{Cy})_{2}, \mathrm{Et}_{3} \mathrm{~N}, \mathrm{Et}_{2} \mathrm{O},-78{ }^{\circ} \mathrm{C}, 2 \mathrm{~h}$, (ii) (S)-10, $-78{ }^{\circ} \mathrm{C} \rightarrow-25{ }^{\circ} \mathrm{C}, 16 \mathrm{~h}, 84 \%$; (b) $\mathrm{MeOTf} \mathrm{DTBMP}, \mathrm{CH}_{2} \mathrm{Cl}_{2}$, $45^{\circ} \mathrm{C}, 24$ h, $75 \%$; (c) $\mathrm{LiBH}_{4}, \mathrm{THF},-78{ }^{\circ} \mathrm{C} \rightarrow$ r.t., 16 h; (d) $\mathrm{Pd} / \mathrm{C}, \mathrm{H}_{2}(1 \mathrm{~atm})$, EtOH, r.t., 16 h; (e) $\mathrm{NaIO}_{4}, \mathrm{MeOH}$, r.t., $20 \mathrm{~min}, 65 \%$ over three steps. 
SCHEME 8. Synthesis of Weinreb Amides $4 \mathbf{a}-\mathbf{f}^{a}$

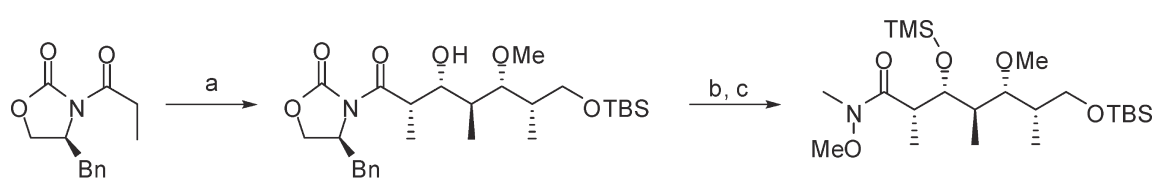

(S)-17

$18 \mathrm{a}$

$4 a$

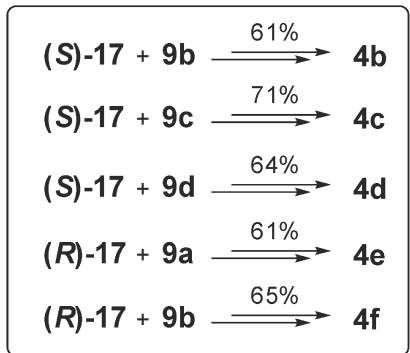

${ }^{a}$ Reagents and conditions: (a) (i) (S)-17, $n$ - BuOTf, $\mathrm{Et}_{3} \mathrm{~N}, \mathrm{CH}_{2} \mathrm{Cl}_{2}, 0^{\circ} \mathrm{C}, 1 \mathrm{~h}$, (ii) $9 \mathrm{a},-78^{\circ} \mathrm{C} \rightarrow 0{ }^{\circ} \mathrm{C}, 90 \mathrm{~min}, 91 \%$; (b) $\mathrm{MeONHMe}^{\circ} \mathrm{HCl}, \mathrm{AlMe}, \mathrm{CH}_{2} \mathrm{Cl}_{2},-$ $20{ }^{\circ} \mathrm{C} \rightarrow$ r.t., $16 \mathrm{~h}, 75 \%$; (c) TMSOTf, 2,6-lutidine, $\mathrm{CH}_{2} \mathrm{Cl}_{2},-30{ }^{\circ} \mathrm{C}, 1 \mathrm{~h}, 93 \%$.

SCHEME 9. Synthesis of the Four Diastereomers $1 \mathbf{a}-\mathbf{f}^{a}$

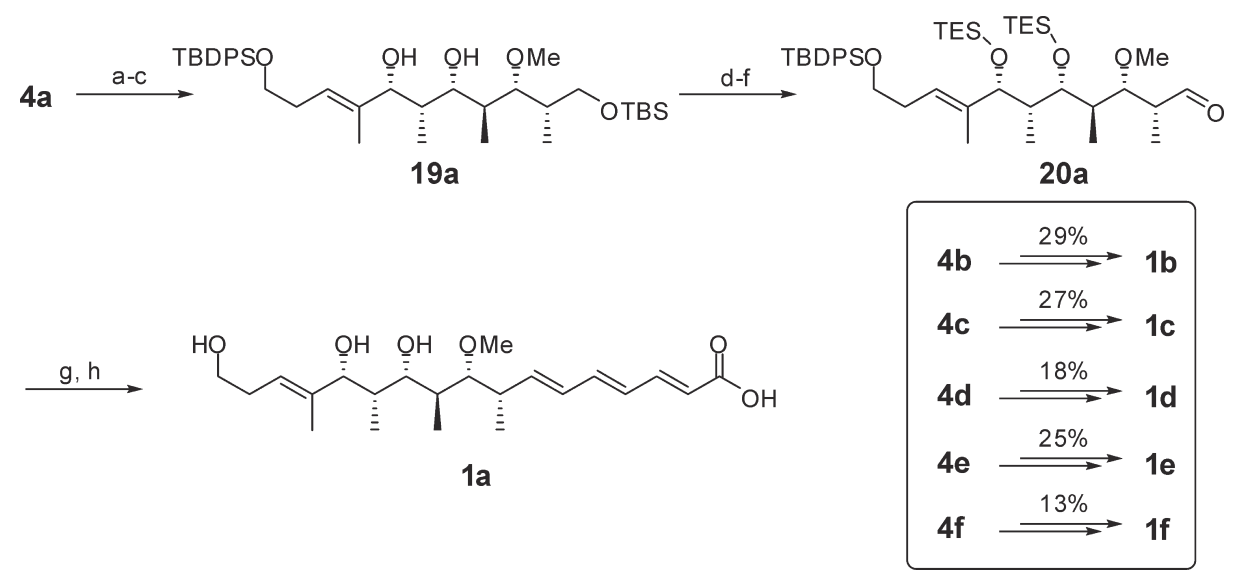

${ }^{a}$ Reagents and conditions: (a) (i) $3, t$ - $\mathrm{BuLi}, \mathrm{Et}_{2} \mathrm{O},-90{ }^{\circ} \mathrm{C}, 10 \mathrm{~min}$, (ii) $4 \mathrm{aa},-78{ }^{\circ} \mathrm{C} \rightarrow-50{ }^{\circ} \mathrm{C}, 1 \mathrm{~h}$; (b) Amberlyst- 15 , MeOH, r.t., $30 \mathrm{~min}, 85 \%$ over two steps; (c) $\mathrm{Zn}\left(\mathrm{BH}_{4}\right)_{2}, \mathrm{Et}_{2} \mathrm{O}, \mathrm{CH}_{2} \mathrm{Cl}_{2},-78^{\circ} \mathrm{C} \rightarrow-50^{\circ} \mathrm{C}, 5 \mathrm{~h}, 91 \%$; (d) $\mathrm{AcOH}$, THF, $\mathrm{H}_{2} \mathrm{O}$, r.t., $16 \mathrm{~h}, 88 \%$; (e) TESOTf, 2,6-lutidine, $\mathrm{CH}_{2} \mathrm{Cl}_{2}, 0{ }^{\circ} \mathrm{C}, 45$ min, $99 \%$; (f) (i) $(\mathrm{COCl})_{2}, \mathrm{DMSO}, \mathrm{CH}_{2} \mathrm{Cl}_{2},-80^{\circ} \mathrm{C} \rightarrow-55^{\circ} \mathrm{C}, 1 \mathrm{~h}$, (ii) $\mathrm{Et}_{3} \mathrm{~N},-80^{\circ} \mathrm{C} \rightarrow$ r.t., $1 \mathrm{~h}$; (g) (i) 2 , LDA, THF, $-78^{\circ} \mathrm{C}, 15 \mathrm{~min}$, (ii) $20 \mathrm{a},-78^{\circ} \mathrm{C} \rightarrow 0{ }^{\circ} \mathrm{C}, 45$ min, $59 \%$ over two steps; (h) TAS-F, DMF, $0{ }^{\circ} \mathrm{C}$, r.t., 9 h, $67 \%$.

\section{SCHEME 10. Synthesis of Model Compounds 21 and 22}

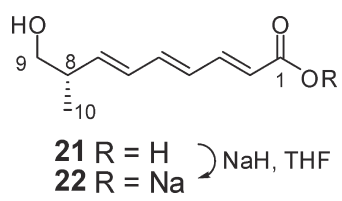

the trienic portion, an inconsistency was immediately noticed. Indeed, a large difference in ${ }^{13} \mathrm{C}$ and ${ }^{1} \mathrm{H}$ NMR chemical shifts was observed between compound $\mathbf{A}$ and all diastereomers with a decreasing impact from position 1 to 7 (Figure 4).

A dilution effect was first assumed to explain this difference, but subsequent experiences ruled out this hypothesis. The observed chemical shift differences were then supposed to be attributed to the presence of a carboxylate salt in natural product $\mathbf{A}$. To prove this assumption and to

(25) Model compound $\mathbf{2 1}$ was prepared from the aldehyde $(\boldsymbol{R})-\mathbf{1 0}$ and phosphonate 2 (through the same sequence as the one described in Scheme 9).

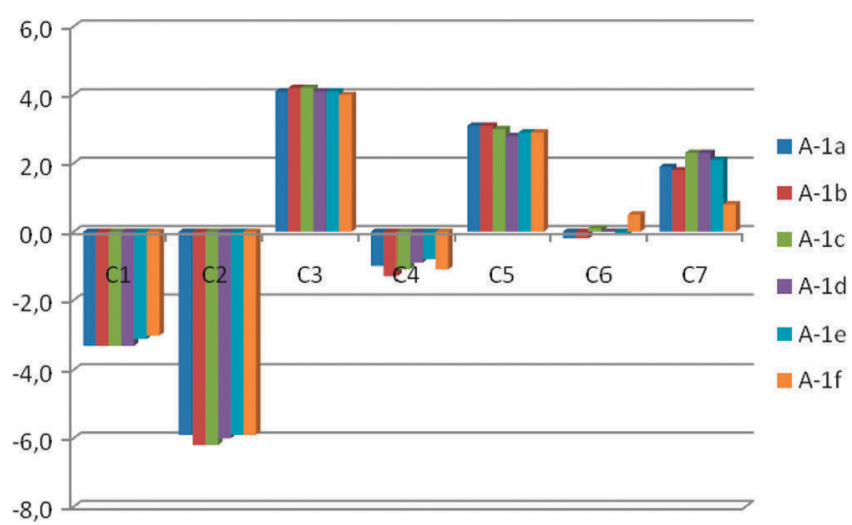

FigURE 4. $\Delta \delta{ }^{13} \mathrm{C}(\mathrm{ppm})$ between $\mathbf{A}$ and $\mathbf{1 a}-\mathbf{f}$ for carbons 1 to 7 .

determine whether this could affect the polypropionate section or not, a model compound $\mathbf{2 1}$ was synthesized ${ }^{25}$ and converted into its corresponding sodium carboxylate salt 22 (Scheme 10). 


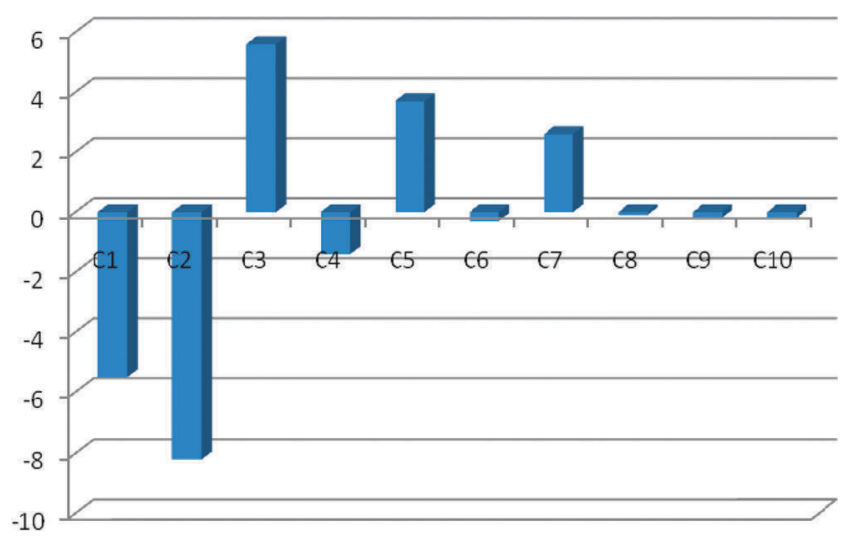

FIGURE 5. $\Delta \delta{ }^{13} \mathrm{C}(\mathrm{ppm})$ between 21 and 22 for carbons $1-10$.

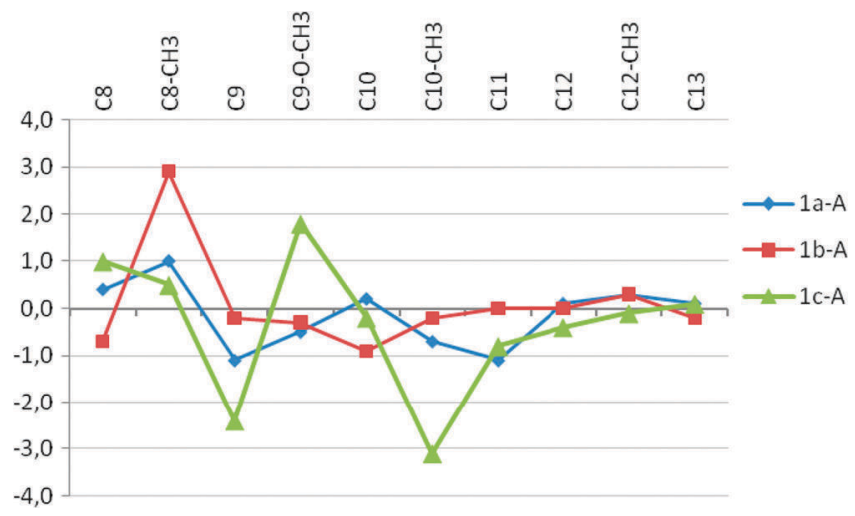

FigURE 6. $\Delta \delta{ }^{13} \mathrm{C}(\mathrm{ppm})$ between $\mathbf{A}$ and $\mathbf{1 a}-\mathbf{c}$ for the $\mathrm{C} 8-\mathrm{C} 13$ subunit.

A chemical shift deviation profile was observed for carbons $\mathrm{C} 1-\mathrm{C} 7$ by ${ }^{13} \mathrm{C}$ NMR data comparison between compounds 21 and 22. Because this deviation was similar to that observed between diastereomers $\mathbf{1} \mathbf{a}-\mathbf{f}$ and $\mathbf{A}$, natural compound $\mathbf{A}$ was then deduced to be extracted as a carboxylate salt, but the nature of the counterion could not be determined.

Unfortunately, the available quantity of natural compound A did not allow its conversion into the corresponding carboxylic acid. However, it is interesting to note that this salt effect does not affect the saturated portion (see C8, C9, and $\mathrm{C} 10$ in Figure 5). An NMR comparison of the central polyketide portion $\mathrm{C} 8-\mathrm{C} 13$ of $\mathbf{1 a}-\mathbf{f}$ with natural compound A was therefore possible.

The differences in the ${ }^{13} \mathrm{C}$ NMR spectra are highlighted in Figures 6 and 7 by plotting the chemical shift difference observed for each carbon of the $\mathrm{C} 8-\mathrm{C} 13$ portion between natural product $\mathbf{A}$ and $\mathbf{1 a}-\mathbf{f}$.

There is a significant difference $(\Delta \delta>1 \mathrm{ppm})$ in the chemical shift of a number of peaks for compounds $\mathbf{1 c}-\mathbf{f}$, most notably at positions $\mathrm{C}$, $\mathrm{C} 9-\mathrm{O}-\mathrm{CH}_{3}$, and $\mathrm{C} 10-\mathrm{CH}_{3}$ for 1c and $\mathbf{1 d}$ and at positions $\mathrm{C} 12, \mathrm{C} 12-\mathrm{CH}_{3}$, and $\mathrm{C} 13$ for $\mathbf{1 e}$ and 1f. Consequently, these structures could not be correlated with the natural product $\mathbf{A}$.

For compounds $\mathbf{1 a}$ and $\mathbf{1 b}$, the difference in ${ }^{13} \mathrm{C}$ NMR chemical shifts is low $(\Delta \delta<1 \mathrm{ppm})$, except for the $\mathrm{C} 8-\mathrm{CH}_{3}$ position of $\mathbf{1 b}(\Delta \delta=2.8 \mathrm{ppm})$. We turned to ${ }^{1} \mathrm{H}$ NMR comparison to clearly distinguish the two compounds (Figure 8).

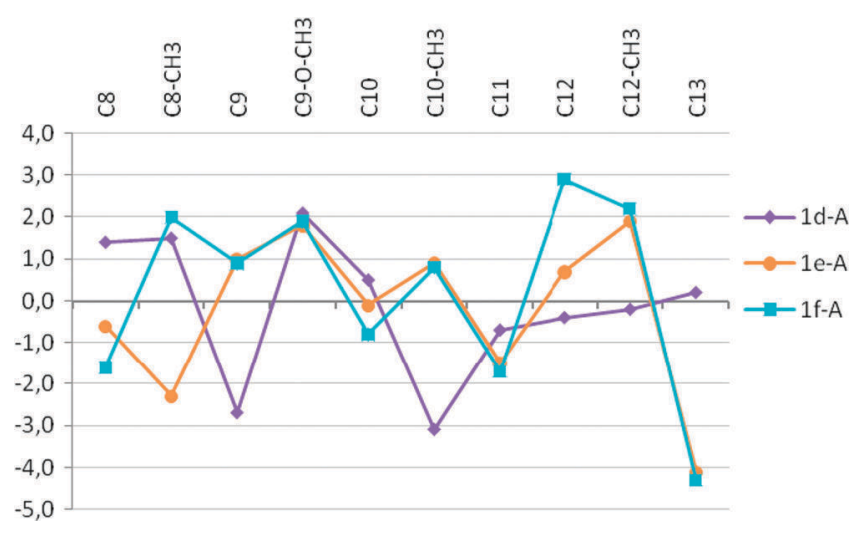

FIGURE 7. $\Delta \delta{ }^{13} \mathrm{C}(\mathrm{ppm})$ between $\mathbf{A}$ and $\mathbf{1 d}-\mathbf{f}$ for the $\mathrm{C} 8-\mathrm{C} 13$ subunit.

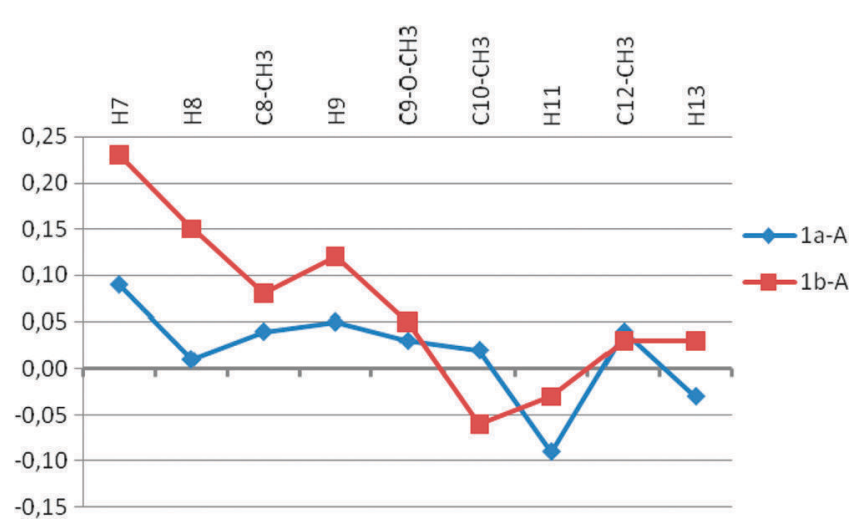

FIGURE 8. $\Delta \delta^{1} \mathrm{H}(\mathrm{ppm})$ between $\mathbf{A}$ and $\mathbf{1 a}$ and $\mathbf{1 b}$ for the $\mathrm{C} 7-\mathrm{C} 13$ subunit.

TABLE 1. Comparison of the ${ }^{1} \mathrm{H}$ and ${ }^{13} \mathrm{C}$ NMR Data for Natural Compound $A$ and Isomer 1a

\begin{tabular}{llllll}
\hline & \multicolumn{2}{c}{ compound A } & & \multicolumn{2}{c}{ isomer 1a } \\
\cline { 2 - 3 } \cline { 6 - 6 } carbon No. & $\delta \mathrm{H}, \mathrm{m},{ }^{3} J[\mathrm{~Hz}]$ & $\delta \mathrm{C}$ & & $\delta \mathrm{H}, \mathrm{m},{ }^{3} J[\mathrm{~Hz}]$ & $\delta \mathrm{C}$ \\
\hline $\mathrm{C} 8$ & $2.53, \mathrm{~m}$ & 41.5 & & $2.54, \mathrm{~m}$ & 41.8 \\
$\mathrm{C} 8-\mathrm{CH}_{3}$ & $1.07, \mathrm{~d}, 6.7$ & 17.2 & & $1.10, \mathrm{~d}, 6.7$ & 18.1 \\
$\mathrm{C} 9$ & $3.27, \mathrm{dd}, 6.7,4.6$ & 88.3 & & $3.32, \mathrm{dd}, 7.4,3.6$ & 87.3 \\
$\mathrm{C} 9-\mathrm{O}-\mathrm{CH}_{3}$ & $3.38, \mathrm{~s}$ & 59.6 & & $3.41, \mathrm{~s}$ & 59.1 \\
$\mathrm{C} 10$ & & 40.1 & $2.03, \mathrm{~m}$ & 40.3 \\
$\mathrm{C} 10-\mathrm{CH}_{3}$ & $0.85, \mathrm{~d}, 7.0$ & 13.0 & & $0.86, \mathrm{~d}, 6.9$ & 12.4 \\
$\mathrm{C} 11$ & $3.57, \mathrm{dd}, 9.6,2.0$ & 75.5 & & $3.49, \mathrm{dd}, 10.1,1.7$ & 74.5 \\
$\mathrm{C} 12$ & & 38.5 & & $1.78, \mathrm{~m}$ & 38.6 \\
$\mathrm{C} 12-\mathrm{CH}_{3}$ & $0.93, \mathrm{~d}, 7.0$ & 7.6 & & $0.96, \mathrm{~d}, 7.0$ & 7.9 \\
$\mathrm{C} 13$ & $3.99, \mathrm{~d}, 7.3$ & 82.1 & $3.97, \mathrm{~d}, 8.1$ & 82.2 \\
\hline
\end{tabular}

In this case, a much closer correlation with natural product $\mathbf{A}$ is observed for compound $\mathbf{1 a}$, especially with regard to protons $\mathrm{H} 7, \mathrm{H} 8, \mathrm{C} 8-\mathrm{CH}_{3}$, and $\mathrm{C} 9-\mathrm{OCH}_{3}$. The small variations $\left(\Delta \delta_{\max }=0.08 \mathrm{ppm}\right.$ for the $\mathrm{C} 8-\mathrm{C} 13$ portion $)$ can be explained by the structural differences between our model and the natural compound. On this basis, the relative configuration of the natural compound $\mathbf{A}$ is assigned as isomer 1a (see Table 1 for full NMR comparison between $\mathbf{A}$ and 1a and Supporting Information for full NMR comparison between $\mathbf{A}$ and $\mathbf{1} \mathbf{b}-\mathbf{f}){ }^{26}$

(26) Analysis of the coupling constants also displays a good correlation between $\mathbf{1 a}$ and $\mathbf{A}$. 


\section{Conclusion}

In summary, the relative stereochemistry of the six contiguous stereogenic centers of the $\mathrm{C} 8-\mathrm{C} 13$ segment of a recently isolated natural compound was convincingly determined. A relevant initial NMR analysis allowed us to decrease the number of putative relative isomers from 32 to 6 . The next step consisted in designing a synthetic model of the $\mathrm{C} 1-\mathrm{C} 19$ part of $\mathbf{A}$, whose isomers were prepared through a highly convergent strategy. With a high predictability, a final thorough comparison of the ${ }^{13} \mathrm{C}$ and ${ }^{1} \mathrm{H}$ NMR data of the natural compound with those of the model isomers enabled the full relative structural assignment of this large part of the natural compound.

\section{Experimental Section}

$(2 E, 4 E)$-2-(Trimethylsilyl)ethyl Hexa-2,4-dienoate 6. To a cooled $\left(0^{\circ} \mathrm{C}\right)$ solution of sorbic acid $5(1.0 \mathrm{~g}, 8.9 \mathrm{mmol}, 1.0$ equiv) in THF $(60 \mathrm{~mL})$ were added successively trimethylsilylethanol (1.7 mL, $11.6 \mathrm{mmol}, 1.3$ equiv), triphenylphosphine (4.7 g, $17.8 \mathrm{mmol}, 2.0$ equiv), and DIAD (3.5 mL, $17.8 \mathrm{mmol}, 2$ equiv). The mixture was stirred at this temperature for $3 \mathrm{~h}$. The solvent was then removed in vacuo, and the residue was purified by chromatography on silica gel (cyclohexane/EtOAc 100:0 to $85: 15)$ to yield ester $6(1.6 \mathrm{~g}, 83 \%$ yield $) .{ }^{1} \mathrm{H}$ NMR $(300 \mathrm{MHz}$, $\left.\mathrm{CDCl}_{3}\right) \delta 0.04(\mathrm{~s}, 9 \mathrm{H}), 1.01(\mathrm{~m}, 2 \mathrm{H}), 1.84(\mathrm{~d}, J=5.5 \mathrm{~Hz}, 3 \mathrm{H}), 4.22$ $(\mathrm{m}, 2 \mathrm{H}), 5.75(\mathrm{~d}, J=15.9 \mathrm{~Hz}, 1 \mathrm{H}), 6.05-6.25(\mathrm{~m}, 2 \mathrm{H}), 7.23(\mathrm{dd}$, $J=15.9,9.9 \mathrm{~Hz}, 1 \mathrm{H}) .{ }^{13} \mathrm{C} \mathrm{NMR}\left(75 \mathrm{MHz}, \mathrm{CDCl}_{3}\right) \delta-1.4$ $\left(3 \mathrm{CH}_{3}\right), 17.3\left(\mathrm{CH}_{2}\right), 18.6\left(\mathrm{CH}_{3}\right), 62.3\left(\mathrm{CH}_{2}\right), 119.2(\mathrm{CH}), 129.8$ $(\mathrm{CH}), 139.1(\mathrm{CH}), 144.7(\mathrm{CH}), 167.4(\mathrm{C})$. IR (Film) v 2981, 1721, $1644,1245,1192,1147,1111 \mathrm{~cm}^{-1}$.

$(2 E, 4 E)$-2-(Trimethylsilyl)ethyl 6-(Diethoxyphosphoryl)hexa2,4-dienoate 2. Ester 6 (1.6 g, $7.4 \mathrm{mmol}, 1.0$ equiv) was dissolved in $\mathrm{CH}_{2} \mathrm{Cl}_{2}(70 \mathrm{~mL})$. The solution was flushed with argon for $10 \mathrm{~min}$. Allylbromide (3.2 mL, $36.9 \mathrm{mmol}, 5.0$ equiv) and Grubbs-Hoveyda catalyst second generation $(0.1 \mathrm{~g}, 0.2 \mathrm{mmol}$, $3 \mathrm{~mol} \%$ ) were then added successively. The mixture was stirred at room temperature for 2 days. The solvent was then removed under reduced pressure and the residue was purified by chromatography on silica gel (cyclohexane/Et ${ }_{2} \mathrm{O} 97.5: 2.5-80: 20$ ) to afford the expected bromide ( $1.3 \mathrm{~g}, 62 \%$ yield $)$ as a yellow liquid. ${ }^{1} \mathrm{H}$ NMR $\left(300 \mathrm{MHz}, \mathrm{CDCl}_{3}\right) \delta 0.05(\mathrm{~s}, 9 \mathrm{H}), 1.02(\mathrm{~m}, 2 \mathrm{H}), 4.03$ $(\mathrm{d}, J=7.2 \mathrm{~Hz}, 2 \mathrm{H}), 4.25(\mathrm{~m}, 2 \mathrm{H}), 5.92(\mathrm{~d}, J=15.3 \mathrm{~Hz}, 1 \mathrm{H}), 6.23$ $(\mathrm{dt}, J=15.6,7.2 \mathrm{~Hz}, 1 \mathrm{H}), 6.38(\mathrm{dd}, J=15.6,10.8 \mathrm{~Hz}, 1 \mathrm{H}), 7.24$ $(\mathrm{dd}, J=15.3,10.8 \mathrm{~Hz}, 1 \mathrm{H}) .{ }^{13} \mathrm{C} \mathrm{NMR}\left(75 \mathrm{MHz}, \mathrm{CDCl}_{3}\right) \delta-1.5$ $\left(3 \mathrm{CH}_{3}\right), 17.3\left(\mathrm{CH}_{2}\right), 31.3\left(\mathrm{CH}_{2}\right), 62.8\left(\mathrm{CH}_{2}\right), 123.5(\mathrm{CH}), 131.9$ $(\mathrm{CH}), 136.4(\mathrm{CH}), 142.3(\mathrm{CH}), 166.6(\mathrm{C})$. IR (Film) $v 2985,1712$, $1642,1330,1252,1191,1147,832 \mathrm{~cm}^{-1}$.

The previous bromide (1.2 g, $4.3 \mathrm{mmol}, 1.0$ equiv) was dissolved in triethylphosphite $(5.0 \mathrm{~mL}, 29.9 \mathrm{mmol}, 7.0$ equiv) and the mixture was heated at $120^{\circ} \mathrm{C}$ for $1 \mathrm{~h}$. The solution was then cooled down to $70^{\circ} \mathrm{C}$ and the excess triethylphosphite was removed under reduced pressure $(\sim 1 \mathrm{mmHg})$. The crude product 2 ( $1.5 \mathrm{~g}, 100 \%$ yield) was used without purification. ${ }^{1} \mathrm{H}$ NMR $\left(300 \mathrm{MHz}, \mathrm{CDCl}_{3}\right) \delta 0.01(\mathrm{~s}, 9 \mathrm{H}), 0.97-1.05(\mathrm{~m}, 2 \mathrm{H})$, $1.27-1.36(\mathrm{~m}, 6 \mathrm{H}), 2.71(\mathrm{dd}, J=24.0,7.7 \mathrm{~Hz}, 2 \mathrm{H}), 4.05-4.15(\mathrm{~m}$, $4 \mathrm{H}), 4.19-4.26(\mathrm{~m}, 2 \mathrm{H}), 5.83(\mathrm{~d}, J=15.5 \mathrm{~Hz}, 1 \mathrm{H}), 6.05(\mathrm{dq}, J=$ $15.9,7.7 \mathrm{~Hz}, 1 \mathrm{H}), 6.30(\mathrm{ddd}, J=15.9,11.0,4.9 \mathrm{~Hz}, 1 \mathrm{H}), 7.23(\mathrm{dd}$, $J=15.5,11.0 \mathrm{~Hz}, 1 \mathrm{H}) .{ }^{13} \mathrm{C} \mathrm{NMR}\left(75 \mathrm{MHz}, \mathrm{CDCl}_{3}\right) \delta-1.5$ $\left(3 \mathrm{CH}_{3}\right), 16.4\left(\mathrm{~d}, 2 \mathrm{CH}_{3},{ }^{3} J_{\mathrm{C} / P}=5.9 \mathrm{~Hz}\right), 17.3\left(\mathrm{CH}_{2}\right), 31.3\left(\mathrm{~d}, \mathrm{CH}_{2}\right.$, $\left.{ }^{1} J_{C / P}=139.5 \mathrm{~Hz}\right), 62.2\left(\mathrm{~d}, 2 \mathrm{CH}_{2},{ }^{2} J_{C / P}=6.8 \mathrm{~Hz}\right), 62.6\left(\mathrm{CH}_{2}\right)$, $121.5\left(\mathrm{~d}, \mathrm{CH},{ }^{5} J_{C / P}=4.1 \mathrm{~Hz}\right), 131.3\left(\mathrm{~d}, \mathrm{CH},{ }^{3} J_{\mathrm{C} / P}=12.6 \mathrm{~Hz}\right)$, $132.9\left(\mathrm{~d}, \mathrm{CH},{ }^{2} J_{C / P}=14.5 \mathrm{~Hz}\right), 167.1(\mathrm{C}), 143.3\left(\mathrm{~d}, \mathrm{CH},{ }^{4} J_{\mathrm{C} / P}=\right.$ $4.7 \mathrm{~Hz}$ ). IR (Film) v 2954, 1720, 1251, 1168, 1027, 977, $838 \mathrm{~cm}^{-1}$.

(E)-4-(Tributylstannyl)pent-3-en-1-ol 8. To a solution of $\left(\mathrm{Bu}_{3} \mathrm{Sn}\right)_{2}(19.7 \mathrm{~mL}, 50.3 \mathrm{mmol}, 1.9$ equiv) in THF $(20 \mathrm{~mL})$ at
$-40{ }^{\circ} \mathrm{C}$ was slowly added $n$-BuLi (1.6 M solution in hexanes, $33.1 \mathrm{~mL}, 31.7 \mathrm{mmol}, 2.0$ equiv). The mixture was stirred for $15 \mathrm{~min}$ at $-40^{\circ} \mathrm{C}$ before being added via cannula to a suspension of $\mathrm{CuCN}$ (2.4 g, $26.5 \mathrm{mmol}, 1.0$ equiv) in $\mathrm{Et}_{2} \mathrm{O}(40 \mathrm{~mL})$. The yellow solution was stirred for $1 \mathrm{~h}$ between $-30^{\circ} \mathrm{C}$ and $-20^{\circ} \mathrm{C}$. In parallel, to a solution of commercial 2,3-dihydrofuran 7 (2.0 mL, $26.5 \mathrm{mmol}, 1.0$ equiv) in THF $(18 \mathrm{~mL})$ at $-60{ }^{\circ} \mathrm{C}$ was added tert-BuLi (1.5 M solution in pentane, $21.2 \mathrm{~mL}$, $31.7 \mathrm{mmol}, 1.2$ equiv). The yellow solution was stirred for $10 \mathrm{~min}$ at $-60{ }^{\circ} \mathrm{C}$ then for $50 \mathrm{~min}$ at $0{ }^{\circ} \mathrm{C}$. The solution of lithio-dihydrofuran, prepared above, was then added via cannula to the cyanocuprate and the reaction mixture was stirred at $-5{ }^{\circ} \mathrm{C}$ for $90 \mathrm{~min}$. At $-30{ }^{\circ} \mathrm{C}$ was added freshly distilled MeI (11.5 mL, $185.0 \mathrm{mmol}, 7.0$ equiv). The reaction mixture was allowed to warm to room temperature and stirred for $5 \mathrm{~h}$. Finally the reaction mixture was poured into a mixture of a saturated aqueous $\mathrm{NH}_{4} \mathrm{Cl}$ solution and concentrated ammonia (4:1) at $0^{\circ} \mathrm{C}$ and stirring was maintained for $1 \mathrm{~h}$ at $20^{\circ} \mathrm{C}$ before extraction with diethyl ether. The organic layer was washed with water, brine, dried over $\mathrm{MgSO}_{4}$ and the solvent was removed under reduced pressure. The crude residue was purified by chromatography on basic silica gel (cyclohexane/EtOAc 100:0-70:30) to give $9.13 \mathrm{~g}(92 \%$ yield $)$ of the title compound 8. ${ }^{1} \mathrm{H}$ NMR $\left(400 \mathrm{MHz}, \mathrm{CDCl}_{3}\right) \delta 0.80-1.01(\mathrm{~m}, 15 \mathrm{H}), 1.20-$ $1.40(\mathrm{~m}, 6 \mathrm{H}), 1.42-1.57(\mathrm{~m}, 6 \mathrm{H}), 1.87(\mathrm{~d}, J=1.8 \mathrm{~Hz}, 3 \mathrm{H}), 2.42$ $(\mathrm{q}, J=6.4 \mathrm{~Hz}, 2 \mathrm{H}), 3.66(\mathrm{t}, J=5.9 \mathrm{~Hz}, 2 \mathrm{H}), 5.51(\mathrm{qd}, J=7.3,1.8$ $\mathrm{Hz}, 1 \mathrm{H}) .{ }^{13} \mathrm{C}$ NMR $\left(100 \mathrm{MHz}, \mathrm{CDCl}_{3}\right) \delta 9.1\left(3 \mathrm{CH}_{2}\right), 13.7$ $\left(3 \mathrm{CH}_{3}\right), 19.3\left(\mathrm{CH}_{3}\right), 27.4\left(3 \mathrm{CH}_{2}\right), 29.2\left(3 \mathrm{CH}_{2}\right), 31.7\left(\mathrm{CH}_{2}\right)$, $62.3\left(\mathrm{CH}_{2}\right), 135.7(\mathrm{CH}), 142.5(\mathrm{C})$. HRMS (EI+) $\mathrm{m} / \mathrm{z}$ Calcd for $\mathrm{C}_{17} \mathrm{H}_{36} \mathrm{OSn}\left(\mathrm{M}^{+}\right)$: 376.1788. Found: 376.1776. IR (Film) $v$ $3340,2958,2925,2871,2853,1463,1046 \mathrm{~cm}^{-1}$.

(E)-(4-Bromopent-3-enyloxy)(tert-butyl)diphenylsilane 3a. Alcohol 8 (3.0 g, $8.0 \mathrm{mmol}, 1.0$ equiv) was dissolved in dry DMF $(10 \mathrm{~mL})$ at room temperature. To this solution were successively added imidazole (1.7 g, $24.8 \mathrm{mmol}, 3.1$ equiv) and TBDPSCl ( $3.3 \mathrm{~g}, 12.0 \mathrm{mmol}, 1.5$ equiv). After stirring for $1.5 \mathrm{~h}$, the mixture was quenched with saturated aqueous solution of $\mathrm{NH}_{4} \mathrm{Cl}$ and extracted with $\mathrm{Et}_{2} \mathrm{O}$. The organic layer was dried over $\mathrm{MgSO}_{4}$ and the solvent was removed under reduced pressure. The residue was purified by chromatography on basic silica gel (cyclohexane/ $\left.\mathrm{Et}_{2} \mathrm{O} 100: 0-90: 10\right)$ to give $4.9 \mathrm{~g}$ (100\% yield) of the silyl ether. ${ }^{1} \mathrm{H}$ NMR $\left(300 \mathrm{MHz}, \mathrm{CDCl}_{3}\right) \delta 0.83-0.94(\mathrm{~m}$, $15 \mathrm{H}), 1.06(\mathrm{~s}, 9 \mathrm{H}), 1.26-1.37(\mathrm{~m}, 6 \mathrm{H}), 1.45-1.55(\mathrm{~m}, 6 \mathrm{H}), 1.82$ $(\mathrm{s}, 3 \mathrm{H}), 2.42(\mathrm{q}, J=6.7 \mathrm{~Hz}, 2 \mathrm{H}), 3.69(\mathrm{t}, J=6.7 \mathrm{~Hz}, 2 \mathrm{H}), 5.61(\mathrm{t}$, $J=6.7 \mathrm{~Hz}, 1 \mathrm{H}), 7.35-7.45(\mathrm{~m}, 6 \mathrm{H}), 7.66-7.73(\mathrm{~m}, 4 \mathrm{H}) .{ }^{13} \mathrm{C}$ NMR $\left(75 \mathrm{MHz}, \mathrm{CDCl}_{3}\right) \delta 9.0\left(3 \mathrm{CH}_{2}\right), 13.7\left(3 \mathrm{CH}_{3}\right), 19.2$ $\left(\mathrm{C}+\mathrm{CH}_{3}\right), 26.8\left(3 \mathrm{CH}_{3}\right), 27.4\left(3 \mathrm{CH}_{2}\right), 29.2\left(3 \mathrm{CH}_{2}\right), 31.6\left(\mathrm{CH}_{2}\right)$, $63.5\left(\mathrm{CH}_{2}\right), 127.6(4 \mathrm{CH}), 129.5(2 \mathrm{CH}), 134.1(2 \mathrm{C}), 135.6(4 \mathrm{CH})$, $136.8(\mathrm{CH}), 140.0(\mathrm{C})$. HRMS (EI+) $\mathrm{m} / z$ Calcd for $\mathrm{C}_{33} \mathrm{H}_{54} \mathrm{OS}-$ iSn $\left(\mathrm{M}^{+}\right)$: 614.2966. Found: 614.3002. IR (film) $v$ 2956, 2927, 2856, 1463, 1428, 1111, $701 \mathrm{~cm}^{-1}$.

NBS ( $2.8 \mathrm{~g}, 16.0 \mathrm{mmol}, 2.0$ equiv) was added to a solution of the silyl ether ( $4.9 \mathrm{~g}, 8.0 \mathrm{mmol}, 1.0$ equiv) in $\mathrm{CH}_{2} \mathrm{Cl}_{2}(60 \mathrm{~mL})$ at $0{ }^{\circ} \mathrm{C}$. After $1 \mathrm{~h}$ at $0{ }^{\circ} \mathrm{C}$, the mixture was concentrated in vacuo. The residue was purified by chromatography on silica gel (cyclohexane $/ \mathrm{Et}_{2} \mathrm{O}$ 100:0-70:30) to afford vinyl bromide 3a (3.2 g, 100\% yield). ${ }^{1} \mathrm{H}$ NMR $\left(300 \mathrm{MHz}, \mathrm{CDCl}_{3}\right) \delta 1.06(\mathrm{~s}$, $9 \mathrm{H}), 2.18(\mathrm{~s}, 3 \mathrm{H}), 2.24(\mathrm{q}, J=6.7 \mathrm{~Hz}, 2 \mathrm{H}), 3.66(\mathrm{t}, J=6.7 \mathrm{~Hz}, 2 \mathrm{H})$, $5.86(\mathrm{t}, J=6.7 \mathrm{~Hz}, 1 \mathrm{H}), 7.35-7.45(\mathrm{~m}, 6 \mathrm{H}), 7.65-7.75(\mathrm{~m}, 4 \mathrm{H})$. ${ }^{13} \mathrm{C} \mathrm{NMR}\left(75 \mathrm{MHz}, \mathrm{CDCl}_{3}\right) \delta 19.1(\mathrm{C}), 23.3\left(\mathrm{CH}_{3}\right), 26.8\left(3 \mathrm{CH}_{3}\right)$, $32.9\left(\mathrm{CH}_{2}\right), 62.6\left(\mathrm{CH}_{2}\right), 121.0(\mathrm{C}), 127.7(4 \mathrm{CH}), 128.8(\mathrm{CH})$, 129.7 (2CH), 133.7 (2C), 135.6 (4CH). IR (film) v 3070, 2956, $2930,2857,1427,1111,701 \mathrm{~cm}^{-1}$

$(2 S, 4 R, 5 R, 6 S)-7-($ tert-Butyldimethylsilyloxy)-5-hydroxy-4,6dimethyl-3-oxoheptan-2-yl Benzoate 15a. To a cooled solution of $\mathrm{ClB}(\mathrm{Cy})_{2}(5 \mathrm{~mL}, 22.8 \mathrm{mmol}, 1.5$ equiv $)$ in anhydrous $\mathrm{Et}_{2} \mathrm{O}(40$ $\mathrm{mL})$ at $-78^{\circ} \mathrm{C}$ were added dropwise freshly distilled $\mathrm{Me}_{2} \mathrm{NEt}$ (3.0 mL, $27.4 \mathrm{mmol}, 1.8$ equiv) followed by ketone 12 (3.1 g, 
$15.2 \mathrm{mmol}, 1.0$ equiv) in anhydrous $\mathrm{Et}_{2} \mathrm{O}(15 \mathrm{~mL})$. The resulting milky mixture was stirred at $0^{\circ} \mathrm{C}$ for $2 \mathrm{~h}$. The solution was then cooled to $-78^{\circ} \mathrm{C}$ before dropwise addition of aldehyde $(\boldsymbol{S})-\mathbf{1 0}^{4 \mathrm{c}}$ ( $4.6 \mathrm{~g}, 22.8 \mathrm{mmol}, 1.5$ equiv). The solution was stirred for $2 \mathrm{~h}$ at $-78^{\circ} \mathrm{C}$. The mixture was then maintained overnight at $-25^{\circ} \mathrm{C}$ without stirring. After one night, the mixture was stirred for 30 min at $0{ }^{\circ} \mathrm{C}$. The reaction was then quenched by addition of $\mathrm{MeOH}(50 \mathrm{~mL}), \mathrm{pH} 7$ phosphate buffer $(50 \mathrm{~mL})$, and $\mathrm{H}_{2} \mathrm{O}_{2}$ $(35 \%, 50 \mathrm{~mL})$. The mixture was stirred for $1 \mathrm{~h}$ at room temperature, before being partitioned between water and $\mathrm{CH}_{2} \mathrm{Cl}_{2}$. The aqueous layer was extracted with $\mathrm{CH}_{2} \mathrm{Cl}_{2}(2 \times)$. The combined organic extracts were dried $\left(\mathrm{MgSO}_{4}\right)$ and concentrated in vacuo. The residue was purified by column chromatography (cyclohexane/Et ${ }_{2} \mathrm{O} 90: 10-80: 20$ ) to afford aldol 15a $\left(6.1 \mathrm{~g}, 98 \%\right.$ yield) as colorless oil. RN: $261968-17-6 .{ }^{1} \mathrm{H}$ NMR $\left(400 \mathrm{MHz}, \mathrm{CDCl}_{3}\right) \delta 0.04(\mathrm{~s}, 6 \mathrm{H}), 0.87(\mathrm{~s}, 9 \mathrm{H}), 0.93(\mathrm{~d}, J=$ $7.3 \mathrm{~Hz}, 3 \mathrm{H}), 1.09$ (d, $J=6.9 \mathrm{~Hz}, 3 \mathrm{H}), 1.57$ (d, $J=6.9 \mathrm{~Hz}, 3 \mathrm{H})$, $1.63-1.83(\mathrm{~m}, 1 \mathrm{H}), 2.99(\mathrm{dq}, J=9.6,6.9 \mathrm{~Hz}, 1 \mathrm{H}), 3.06(\mathrm{~d}, J=$ $2.3 \mathrm{~Hz}, 1 \mathrm{H}), 3.68(\mathrm{dd}, J=9.6,4.6 \mathrm{~Hz}, 1 \mathrm{H}), 3.79(\mathrm{dd}, J=9.6$, $3.7 \mathrm{~Hz}, 1 \mathrm{H}), 4.11(\mathrm{dt}, J=9.6,2.3 \mathrm{~Hz}, 1 \mathrm{H}), 5.43(\mathrm{q}, J=6.9 \mathrm{~Hz}$, $1 \mathrm{H}), 7.44(\mathrm{t}, J=7.3 \mathrm{~Hz}, 2 \mathrm{H}), 7.57(\mathrm{tt}, J=7.3,1.4 \mathrm{~Hz}, 1 \mathrm{H}), 8.07$ $(\mathrm{m}, 2 \mathrm{H}) .{ }^{13} \mathrm{C}$ NMR $\left(100 \mathrm{MHz}, \mathrm{CDCl}_{3}\right) \delta-5.7\left(\mathrm{CH}_{3}\right),-5.6$ $\left(\mathrm{CH}_{3}\right), 8.9\left(\mathrm{CH}_{3}\right), 13.7\left(\mathrm{CH}_{3}\right), 15.4\left(\mathrm{CH}_{3}\right), 18.2(\mathrm{C}), 25.8\left(3 \mathrm{CH}_{3}\right)$, $35.3(\mathrm{CH}), 45.8(\mathrm{CH}), 68.5\left(\mathrm{CH}_{2}\right), 75.3(\mathrm{CH}), 75.6(\mathrm{CH}), 128.4$ $(2 \mathrm{CH}), 129.7(\mathrm{C}), 129.8(2 \mathrm{CH}), 133.1(\mathrm{CH}), 165.9(\mathrm{C}), 211.0(\mathrm{C})$. HRMS (EI+) $m / z$ Calcd for $\mathrm{C}_{22} \mathrm{H}_{36} \mathrm{O}_{5} \mathrm{Si}\left(\mathrm{M}^{+}\right)$: 408.2332 . Found: 408.2293. $[\alpha]_{\mathrm{D}}=+5.0\left(c=0.8, \mathrm{CHCl}_{3}\right)$. IR (film) $v$ $3505,2932,2855,1720 \mathrm{~cm}^{-1}$.

$(2 R, 3 R, 4 S)-5$-(tert-Butyldimethylsilyloxy)-3-methoxy-2,4-dimethylpentanal 9a. Aldol 15a ( $4.2 \mathrm{~g}, 10.1 \mathrm{mmol}, 1.0$ equiv) was dissolved in anhydrous $\mathrm{CH}_{2} \mathrm{Cl}_{2}(120 \mathrm{~mL})$ at room temperature. To this solution was added 2,6-di-tert-butyl-4-methylpyridine (25.0 g, $121.9 \mathrm{mmol}, 12.0$ equiv) followed by methyl trifluoromethanesulfonate $(6.9 \mathrm{~mL}, 61.0 \mathrm{mmol}, 6.0$ equiv). The solution was heated to reflux of $\mathrm{CH}_{2} \mathrm{Cl}_{2}$ for $8 \mathrm{~h}$, and then 6.0 equiv of methyl trifluoromethanesulfonate were further added. The solution was refluxed overnight. The mixture was then cooled to $0{ }^{\circ} \mathrm{C}$ and a $7 \mathrm{M}$ aqueous solution of $\mathrm{NH}_{4} \mathrm{OH}(17.0 \mathrm{~mL}$, $120 \mathrm{mmol}, 12.0$ equiv) diluted in water $(120 \mathrm{~mL})$ was added dropwise very carefully. Finally, the mixture was extracted with $\mathrm{Et}_{2} \mathrm{O}$, dried over $\mathrm{MgSO}_{4}$, and solvents were removed in vacuo. The residue was purified by column chromatography (cyclohexane $/ \mathrm{Et}_{2} \mathrm{O}$ 100:0-90:10) to afford the methylated aldol product 16a (3.3 g, 76\% yield) as pale yellow oil. ${ }^{1} \mathrm{H}$ NMR (400 $\left.\mathrm{MHz}, \mathrm{CDCl}_{3}\right) \delta 0.04(\mathrm{~s}, 3 \mathrm{H}), 0.05(\mathrm{~s}, 3 \mathrm{H}), 0.79(\mathrm{~d}, J=6.9 \mathrm{~Hz}$, $3 \mathrm{H}), 0.89(\mathrm{~s}, 9 \mathrm{H}), 1.07(\mathrm{~d}, J=6.9 \mathrm{~Hz}, 3 \mathrm{H}), 1.56(\mathrm{~d}, J=7.3 \mathrm{~Hz}$, $3 \mathrm{H}), 1.70-1.90(\mathrm{~m}, 1 \mathrm{H}), 3.05(\mathrm{dq}, J=10.1,6.9 \mathrm{~Hz}, 1 \mathrm{H}), 3.27(\mathrm{~s}$, $3 \mathrm{H}), 3.41-3.61(\mathrm{~m}, 2 \mathrm{H}), 3.75(\mathrm{dd}, J=10.1,1.8 \mathrm{~Hz}, 1 \mathrm{H}), 5.41$ (q, $J=7.3 \mathrm{~Hz}, 1 \mathrm{H}), 7.44(\mathrm{~m}, 2 \mathrm{H}), 7.57(\mathrm{tt}, J=7.3,0.9 \mathrm{~Hz}, 1 \mathrm{H}), 8.09$ $(\mathrm{m}, 2 \mathrm{H}) .{ }^{13} \mathrm{C}$ NMR $\left(100 \mathrm{MHz}, \mathrm{CDCl}_{3}\right) \delta-5.4\left(\mathrm{CH}_{3}\right),-5.3$ $\left(\mathrm{CH}_{3}\right), 9.2\left(\mathrm{CH}_{3}\right), 14.2\left(\mathrm{CH}_{3}\right), 14.9\left(\mathrm{CH}_{3}\right), 18.2(\mathrm{C}), 25.9\left(3 \mathrm{CH}_{3}\right)$, $37.4(\mathrm{CH}), 45.1(\mathrm{CH}), 60.8\left(\mathrm{CH}_{3}\right), 65.2\left(\mathrm{CH}_{2}\right), 75.2(\mathrm{CH}), 81.6$ $(\mathrm{CH}), 128.4(2 \mathrm{CH}), 129.7(\mathrm{C}), 129.8(2 \mathrm{CH}), 133.1(\mathrm{CH}), 165.8$ (C), 210.2 (C). HRMS (EI+) $m / z$ Calcd for $\mathrm{C}_{23} \mathrm{H}_{38} \mathrm{O}_{5} \mathrm{Si}\left(\mathrm{M}^{+}\right)$: 422.2489. Found: 422.2508. $[\alpha]_{\mathrm{D}}=+22.1\left(c=1.7, \mathrm{CHCl}_{3}\right)$. IR (film) $v$ 2958, 2935, 2898, 2858, 1664, 1462, 1385, 1251, 1130, $1075,1056,997,890,838,775 \mathrm{~cm}^{-1}$.

The methylated aldol compound 16a $(3.7 \mathrm{~g}, 8.7 \mathrm{mmol}$, 1.0 equiv) was dissolved in THF $(40 \mathrm{~mL})$ at $-78{ }^{\circ} \mathrm{C}$ before addition of $\mathrm{LiBH}_{4}(2.0 \mathrm{M}$ solution in THF, $87.0 \mathrm{~mL}$, $174.0 \mathrm{mmol}, 20.0$ equiv). The solution was allowed to warm to room temperature and stirred overnight. At $0{ }^{\circ} \mathrm{C}$, water $(100 \mathrm{~mL})$ was added slowly followed by a saturated aqueous solution of Rochelle salt $(100 \mathrm{~mL})$. The mixture was stirred for $1 \mathrm{~h}$ at room temperature before being partitioned between $\mathrm{CH}_{2} \mathrm{Cl}_{2}$ and saturated aqueous $\mathrm{NH}_{4} \mathrm{Cl}$. The aqueous layer was extracted with $\mathrm{CH}_{2} \mathrm{Cl}_{2}(2 \times)$. The combined organic layers were dried over $\mathrm{MgSO}_{4}$ and solvents were removed in vacuo. The residue was directly used in the next step without further purification.

Crude diols were diluted in $\mathrm{MeOH}(40 \mathrm{~mL})$ and water $(20 \mathrm{~mL})$ at room temperature. $\mathrm{NaIO}_{4}(11.2 \mathrm{~g}, 52.5 \mathrm{mmol}, 6.0$ equiv) was added and the mixture was stirred for $25 \mathrm{~min}$. The resulting milky solution was quenched by addition of water $(80 \mathrm{~mL})$ and extracted with $\mathrm{Et}_{2} \mathrm{O}$. The combined organic layers were dried over $\mathrm{MgSO}_{4}$ and concentrated in vacuo. The crude residue was purified by column chromatography (cyclohexane/ $\mathrm{Et}_{2} \mathrm{O} 95: 5-$ $85: 15)$ to afford aldehyde $9 \mathrm{a}(2.0 \mathrm{~g}, 84 \%$ yield over two steps $)$ as a colorless oil. ${ }^{1} \mathrm{H}$ NMR $\left(400 \mathrm{MHz}, \mathrm{CDCl}_{3}\right) \delta 0.05(\mathrm{~s}, 6 \mathrm{H}), 0.88$ $(\mathrm{d}, J=6.9 \mathrm{~Hz}, 3 \mathrm{H}), 0.89(\mathrm{~s}, 9 \mathrm{H}), 1.02(\mathrm{~d}, J=7.3 \mathrm{~Hz}, 3 \mathrm{H}), 1.72-$ $1.90(\mathrm{~m}, 1 \mathrm{H}), 2.65(\mathrm{qd}, J=7.3,2.3 \mathrm{~Hz}, 1 \mathrm{H}), 3.41(\mathrm{~s}, 3 \mathrm{H}), 3.42-$ $3.62(\mathrm{~m}, 2 \mathrm{H}), 3.56(\mathrm{dd}, J=7.8,3.7 \mathrm{~Hz}, 1 \mathrm{H}), 9.80(\mathrm{~d}, J=2.3 \mathrm{~Hz}$, 1H). ${ }^{13} \mathrm{C}$ NMR $\left(100 \mathrm{MHz}, \mathrm{CDCl}_{3}\right) \delta-5.5\left(\mathrm{CH}_{3}\right),-5.4\left(\mathrm{CH}_{3}\right)$, $10.7\left(\mathrm{CH}_{3}\right), 11.1\left(\mathrm{CH}_{3}\right), 18.2(\mathrm{C}), 25.9\left(3 \mathrm{CH}_{3}\right), 38.2(\mathrm{CH}), 49.2$ $(\mathrm{CH}), 60.5\left(\mathrm{CH}_{3}\right), 64.8\left(\mathrm{CH}_{2}\right), 82.1(\mathrm{CH}), 204.9(\mathrm{C})$. HRMS $(\mathrm{EI}+) \mathrm{m} / z$ Calcd for $\mathrm{C}_{14} \mathrm{H}_{30} \mathrm{O}_{3} \mathrm{Si}\left(\mathrm{M}^{+}\right)$: 274.1964. Found: 274.1972. $[\alpha]_{\mathrm{D}}=-15.1\left(c=0.7, \mathrm{CHCl}_{3}\right)$. IR (Film) $v 2955$, 2930, 2895, 2857, 1725, 1461, 1091, 836, $775 \mathrm{~cm}^{-1}$.

(S)-4-Benzyl-3-((2S,3R,4S,5R,6S)-7-(tert-butyldimethylsilyloxy)-3-hydroxy-5-methoxy-2,4,6-trimethylheptanoyl)oxazolidin-2-one 18a. $(S)$-4-Benzyl-3-propionyl-2-oxazolidinone $(S)-17$ (595 mg, $2.6 \mathrm{mmol}, 1.4$ equiv) was dissolved in $\mathrm{CH}_{2} \mathrm{Cl}_{2}(4 \mathrm{~mL})$ and cooled to $0{ }^{\circ} \mathrm{C}$. $n$-Bu $\mathrm{BuTf}_{2}\left(1.0 \mathrm{M}\right.$ solution in $\mathrm{CH}_{2} \mathrm{Cl}_{2}$, $2.8 \mathrm{~mL}, 2.8 \mathrm{mmol}, 1.55$ equiv) was added over $5 \mathrm{~min}$, followed by freshly distilled $\mathrm{Et}_{3} \mathrm{~N}(585 \mu \mathrm{L}, 4.2 \mathrm{mmol}, 2.3$ equiv). After $30 \mathrm{~min}$, the solution was cooled to $-78{ }^{\circ} \mathrm{C}$ and aldehyde 9a (500 mg, $1.8 \mathrm{mmol}, 1.0$ equiv) in $\mathrm{CH}_{2} \mathrm{Cl}_{2}(2.5 \mathrm{~mL}$ ) was added via cannula. The mixture was stirred at $-78{ }^{\circ} \mathrm{C}$ for 90 min then at $0{ }^{\circ} \mathrm{C}$ for $1 \mathrm{~h}$. The reaction was quenched at $0{ }^{\circ} \mathrm{C}$ by addition of $\mathrm{pH} 7$ phosphate buffer ( $3 \mathrm{~mL}), \mathrm{MeOH}(7 \mathrm{~mL})$, and $\mathrm{MeOH} / 35 \%$ $\mathrm{H}_{2} \mathrm{O}_{2}(4 \mathrm{~mL}, 2: 1)$. The mixture was stirred for $1 \mathrm{~h}$ before being partitioned between $\mathrm{Et}_{2} \mathrm{O}$ and saturated aqueous $\mathrm{NaCl}$. The combined organic layers were dried over $\mathrm{MgSO}_{4}$ and solvents were removed in vacuo. The crude residue was purified by column chromatography (cyclohexane/ $\mathrm{Et}_{2} \mathrm{O} 80: 20-50: 50$ ) to afford imide 18a (2.4 g, 91\% yield) as a slightly yellow oil. ${ }^{1} \mathrm{H}$ NMR $\left(400 \mathrm{MHz}, \mathrm{CDCl}_{3}\right) \delta 0.05(\mathrm{~s}, 6 \mathrm{H}), 0.84(\mathrm{~d}, J=6.9 \mathrm{~Hz}, 3 \mathrm{H})$, $0.88(\mathrm{~d}, J=6.4 \mathrm{~Hz}, 3 \mathrm{H}), 0.89(\mathrm{~s}, 9 \mathrm{H}), 1.24(\mathrm{~d}, J=6.9 \mathrm{~Hz}, 3 \mathrm{H})$, $1.78-1.82(\mathrm{~m}, 1 \mathrm{H}), 1.90(\operatorname{sext} \mathrm{d}, J=6.9,2.3 \mathrm{~Hz}, 1 \mathrm{H}), 2.76(\mathrm{dd}, J=$ $13.3,9.6 \mathrm{~Hz}, 1 \mathrm{H}), 3.37(\mathrm{dd}, J=13.3,2.7 \mathrm{~Hz}, 1 \mathrm{H}), 3.44(\mathrm{dd}, J=$ $5.9,2.3 \mathrm{~Hz}, 1 \mathrm{H}), 3.45(\mathrm{~s}, 3 \mathrm{H}), 3.50(\mathrm{~d}, J=6.9 \mathrm{~Hz}, 2 \mathrm{H}), 4.02-3.92$ $(\mathrm{m}, 2 \mathrm{H}), 4.17(\mathrm{dd}, J=9.2,2.7 \mathrm{~Hz}, 1 \mathrm{H}), 4.21(\mathrm{dd}, J=9.2,6.9 \mathrm{~Hz}$, $1 \mathrm{H}), 4.36(\mathrm{~s}, 1 \mathrm{H}), 4.70(\mathrm{ddt}, J=9.6,6.9,2.7 \mathrm{~Hz}, 1 \mathrm{H}), 7.19-7.24$ (m, 2H), 7.26-7.37 (m, 3H). $\left.{ }^{13} \mathrm{C} \mathrm{NMR} \mathrm{(100} \mathrm{MHz,} \mathrm{CDCl}_{3}\right) \delta-$ $5.4\left(\mathrm{CH}_{3}\right),-5.3\left(\mathrm{CH}_{3}\right), 8.7\left(\mathrm{CH}_{3}\right), 10.5\left(\mathrm{CH}_{3}\right), 13.6\left(\mathrm{CH}_{3}\right), 18.3$ (C), $26.0\left(3 \mathrm{CH}_{3}\right), 37.8\left(\mathrm{CH}_{2}\right), 38.4(\mathrm{CH}), 38.7(\mathrm{CH}), 41.0(\mathrm{CH})$, $56.0(\mathrm{CH}), 60.7\left(\mathrm{CH}_{3}\right), 66.0\left(\mathrm{CH}_{2}\right), 66.2\left(\mathrm{CH}_{2}\right), 74.3(\mathrm{CH}), 86.0$ $(\mathrm{CH}), 127.4(2 \mathrm{CH}), 129.0(\mathrm{CH}), 129.6(2 \mathrm{CH}), 135.6(\mathrm{C}), 153.4$ (C), 175.7 (C). HRMS (EI+) $m / z$ Calcd for $\mathrm{C}_{27} \mathrm{H}_{45} \mathrm{NO}_{6} \mathrm{Si}\left(\mathrm{M}^{+}\right)$: 507.3016. Found: 507.3024. $[\alpha]_{\mathrm{D}}=+39.2\left(c=2.0, \mathrm{CHCl}_{3}\right)$. IR (Film) $v$ 2955, 2929, 2857, 1782, 1702, 1455, 1387, 1210, 1093, $837,776 \mathrm{~cm}^{-1}$

$(2 S, 3 R, 4 R, 5 R, 6 S)-7-($ tert-Butyldimethylsilyloxy)- $N$-5-dimethoxy- $N-2,4,6$-tetramethyl-3-(trimethylsilyloxy)heptanamide 4a. $\mathrm{N}, \mathrm{O}$-Dimethylhydroxylamine hydrochloride $(0.56 \mathrm{~g}, 5.8 \mathrm{mmol}$, 2.5 equiv) was suspended in $\mathrm{CH}_{2} \mathrm{Cl}_{2}(20 \mathrm{~mL})$ and cooled to $0{ }^{\circ} \mathrm{C}$. $\mathrm{AlMe}_{3}$ (2 $\mathrm{M}$ solution in heptane, $2.9 \mathrm{~mL}, 5.8 \mathrm{mmol}, 2.5$ equiv) was added dropwise over $5 \mathrm{~min}$ and the resulting clear solution was stirred at room temperature for $1 \mathrm{~h}$. Imide 18a $(1.17 \mathrm{~g}$, $2.3 \mathrm{mmol}, 1.0$ equiv) in $\mathrm{CH}_{2} \mathrm{Cl}_{2}(10 \mathrm{~mL})$ was added dropwise at $-20{ }^{\circ} \mathrm{C}$ over $5 \mathrm{~min}$. The reaction mixture was allowed to stir at room temperature overnight and was then transferred via cannula onto a vigorously stirred aqueous tartaric acid $1 \mathrm{M}$ solution $(60 \mathrm{~mL})$ at $0{ }^{\circ} \mathrm{C}$. The mixture was stirred for $5 \mathrm{~h}$ until two layers appeared. The aqueous layer was extracted with $\mathrm{CH}_{2} \mathrm{Cl}_{2}$ and the combined organic layers were washed with 
brine and dried over $\mathrm{MgSO}_{4}$. After removal of the solvent, the residue was purified by column chromatography (cyclohexane/ EtOAc 90:10-70:30) to afford the corresponding Weinreb amide $\left(676 \mathrm{mg}, 75 \%\right.$ yield) as a colorless oil. ${ }^{1} \mathrm{H}$ NMR $\left(400 \mathrm{MHz}, \mathrm{CDCl}_{3}\right) \delta 0.04(\mathrm{~s}, 6 \mathrm{H}), 0.85(\mathrm{~d}, J=6.9 \mathrm{~Hz}, 3 \mathrm{H})$, $0.87(\mathrm{~d}, J=6.9 \mathrm{~Hz}, 3 \mathrm{H}), 0.89(\mathrm{~s}, 9 \mathrm{H}), 1.17(\mathrm{~d}, J=6.9 \mathrm{~Hz}, 3 \mathrm{H})$, $1.88-1.94(\mathrm{~m}, 1 \mathrm{H}), 1.94-2.02(\mathrm{~m}, 1 \mathrm{H}), 2.95-3.10(\mathrm{~m}, 1 \mathrm{H}), 3.19$ $(\mathrm{s}, 3 \mathrm{H}), 3.41(\mathrm{~s}, 3 \mathrm{H}), 3.45-3.65(\mathrm{~m}, 3 \mathrm{H}), 3.71(\mathrm{~s}, 3 \mathrm{H}), 3.80-3.86$ $(\mathrm{m}, 1 \mathrm{H}), 4.08(\mathrm{~d}, J=1.8 \mathrm{~Hz}, 1 \mathrm{H}) \cdot{ }^{13} \mathrm{CNMR}\left(100 \mathrm{MHz}, \mathrm{CDCl}_{3}\right) \delta$ $-5.4\left(2 \mathrm{CH}_{3}\right), 10.3\left(\mathrm{CH}_{3}\right), 11.6\left(\mathrm{CH}_{3}\right), 12.7\left(\mathrm{CH}_{3}\right), 18.3(\mathrm{C}), 25.9$ $\left(3 \mathrm{CH}_{3}\right), 32.2\left(\mathrm{CH}_{3}\right), 37.0(\mathrm{CH}), 37.6(\mathrm{CH}), 38.2(\mathrm{CH}), 59.5$ $\left(\mathrm{CH}_{3}\right), 61.3\left(\mathrm{CH}_{3}\right), 66.6\left(\mathrm{CH}_{2}\right), 73.3(\mathrm{CH}), 83.1(\mathrm{CH}), 177.9$ (C). HRMS (EI+) $m / z$ Calcd for $\mathrm{C}_{19} \mathrm{H}_{41} \mathrm{NO}_{5} \mathrm{Si}\left(\mathrm{M}^{+}\right): 391.2754$. Found: 391.2746. $[\alpha]_{\mathrm{D}}=+5.1\left(c=2.5, \mathrm{CHCl}_{3}\right)$. IR (Film) v 3454, 2957, 2932, 2858, 1641, 1462, 1399, 1255, 1090, 837, $775 \mathrm{~cm}^{-1}$.

This Weinreb amide ( $1.3 \mathrm{~g}, 3.3 \mathrm{mmol}, 1.0$ equiv) was dissolved in $\mathrm{CH}_{2} \mathrm{Cl}_{2}(35 \mathrm{~mL})$ and the reaction mixture was cooled to $-30{ }^{\circ} \mathrm{C} .2,6$-Lutidine ( $1.6 \mathrm{~mL}, 13.3 \mathrm{mmol}, 4.0$ equiv) was added, followed by TMSOTf $(1.2 \mathrm{~mL}, 6.6 \mathrm{mmol}, 2.0$ equiv). After stirring for $1 \mathrm{~h}$ at $-30^{\circ} \mathrm{C}$, the reaction mixture was quenched by addition of saturated aqueous $\mathrm{NH}_{4} \mathrm{Cl}$ at $-30^{\circ} \mathrm{C}$ and the mixture was allowed to warm to room temperature. The mixture was extracted with $\mathrm{CH}_{2} \mathrm{Cl}_{2}$ and the combined organic layers were dried over $\mathrm{MgSO}_{4}$ and the solvent was removed in vacuo. The crude residue was purified by column chromatography (cyclohexane/EtOAc 90:10-75:25) to afford title compound 4a (1.4 mg, 93\% yield) as a colorless oil. ${ }^{1} \mathrm{H}$ NMR $(400 \mathrm{MHz}$, $\left.\mathrm{CDCl}_{3}\right) \delta 0.03(\mathrm{~s}, 6 \mathrm{H}), 0.15(\mathrm{~s}, 9 \mathrm{H}), 0.68(\mathrm{~d}, J=6.9 \mathrm{~Hz}, 3 \mathrm{H}), 0.88$ $(\mathrm{d}, J=6.9 \mathrm{~Hz}, 3 \mathrm{H}), 0.90(\mathrm{~s}, 9 \mathrm{H}), 1.08(\mathrm{~d}, J=6.9 \mathrm{~Hz}, 3 \mathrm{H}), 1.63-$ $1.72(\mathrm{~m}, 2 \mathrm{H}), 3.16(\mathrm{~s}, 3 \mathrm{H}), 3.39(\mathrm{~s}, 3 \mathrm{H}), 3.49-3.41(\mathrm{~m}, 4 \mathrm{H}), 3.72$ $(\mathrm{s}, 3 \mathrm{H}), 3.92-3.95(\mathrm{~m}, 1 \mathrm{H}) .{ }^{13} \mathrm{C} \mathrm{NMR}\left(100 \mathrm{MHz} \mathrm{CDCl}_{3}\right) \delta-5.4$ $\left(\mathrm{CH}_{3}\right),-5.3\left(\mathrm{CH}_{3}\right), 0.9\left(3 \mathrm{CH}_{3}\right), 9.5\left(\mathrm{CH}_{3}\right), 16.1\left(\mathrm{CH}_{3}\right), 17.4$ $\left(\mathrm{CH}_{3}\right), 18.2(\mathrm{C}), 25.9\left(3 \mathrm{CH}_{3}\right), 32.0\left(\mathrm{CH}_{3}\right), 38.1(\mathrm{CH}), 38.9(\mathrm{CH})$, $40.8(\mathrm{CH}), 59.3\left(\mathrm{CH}_{3}\right), 61.3\left(\mathrm{CH}_{3}\right), 65.5\left(\mathrm{CH}_{2}\right), 77.3(\mathrm{CH}), 80.3$ $(\mathrm{CH}), 177.7$ (C). HRMS (EI+) $m / z$ Calcd for $\mathrm{C}_{22} \mathrm{H}_{49} \mathrm{NO}_{5} \mathrm{Si}_{2}$ $\left(\mathrm{M}^{+}\right)$: 463.3149. Found: 463.3161. $[\alpha]_{\mathrm{D}}=+22.1\left(c=1.7, \mathrm{CHCl}_{3}\right)$. IR (Film) $v 2958,2935,2898,2858,1664,1462,1385,1251,1130$, $1075,1056,97,890,838,775 \mathrm{~cm}^{-1}$.

$(9 R, 10 S, 11 S, 12 S, 13 R, 14 S, E)-13-M e t h o x y-2,2,8,10,12,14,-$ 17,17,18,18-decamethyl-3,3-diphenyl-4,16-dioxa-3,17-disilanonadec-7-ene-9,11-diol 19a. Vinyl bromide 3a (1.60 g, $3.98 \mathrm{mmol}$, 3.0 equiv) was diluted in $\mathrm{Et}_{2} \mathrm{O}(20 \mathrm{~mL})$. To remove dissolved $\mathrm{O}_{2}$, the mixture was frozen at $-196^{\circ} \mathrm{C}$ under argon and then allowed to melt in vacuo. This procedure was repeated three times. At $-78^{\circ} \mathrm{C}$, under argon, $t$ - $\mathrm{BuLi}(1.7 \mathrm{M}$ solution in pentane, $4.70 \mathrm{~mL}$, $7.96 \mathrm{mmol}, 6.0$ equiv) was added dropwise. The mixture was stirred at this temperature for $10 \mathrm{~min}$, then amide $\mathbf{4 a}(615 \mathrm{mg}$, $1.33 \mathrm{mmol}, 1.0$ equiv) was quickly added, and the mixture was stirred at $-50{ }^{\circ} \mathrm{C}$ for $1 \mathrm{~h}$. After this time, the reaction mixture was quenched by addition of $4 \mathrm{~mL}$ of $\mathrm{MeOH}$ at $-50{ }^{\circ} \mathrm{C}$. The mixture was then extracted with $\mathrm{Et}_{2} \mathrm{O}(2 \times)$, and the combined organic layers were washed with a saturated aqueous solution of $\mathrm{NH}_{4} \mathrm{Cl}$, dried over $\mathrm{MgSO}_{4}$, and the solvent was removed under reduced pressure. The residue was purified by chromatography on silica gel (cyclohexane/Et ${ }_{2} \mathrm{O}$ 100:0-70:30) to afford the expected enone which could not be separated from the excess of reduced vinyl compound.

This enone was dissolved in $\mathrm{MeOH}(15 \mathrm{~mL})$ at room temperature and 50 beads of Amberlyst- 15 were added. The reaction was monitored by thin layer chromatography and the mixture was filtered as soon as the starting material was totally consumed. The solvent was removed under reduced pressure and the residue was purified by chromatography on silica gel (cyclohexane/EtOAc 100:0-80:20) to give $735 \mathrm{mg}$ (85\% yield over two steps) of the desired $\beta$-keto alcohol. ${ }^{1} \mathrm{H}$ NMR $\left(300 \mathrm{MHz}, \mathrm{CDCl}_{3}\right) \delta 0.03(\mathrm{~s}, 6 \mathrm{H}), 0.81(\mathrm{~d}, J=7.0 \mathrm{~Hz}, 3 \mathrm{H})$, $0.84(\mathrm{~d}, J=6.9 \mathrm{~Hz}, 3 \mathrm{H}), 0.89(\mathrm{~s}, 9 \mathrm{H}), 1.05(\mathrm{~s}, 9 \mathrm{H}), 1.13(\mathrm{~d}, J=$ $7.0 \mathrm{~Hz}, 3 \mathrm{H}), 1.76(\mathrm{~s}, 3 \mathrm{H}), 1.80-1.95(\mathrm{~m}, 2 \mathrm{H}), 2.50(\mathrm{dt}, J=7.3$,
$6.3 \mathrm{~Hz}, 2 \mathrm{H}), 3.37-3.40(\mathrm{~m}, 1 \mathrm{H}), 3.40(\mathrm{~s}, 3 \mathrm{H}), 3.45(\mathrm{dd}, J=6.3$, $2.7 \mathrm{~Hz}, 1 \mathrm{H}), 3.46(\mathrm{dd}, J=9.9,6.2 \mathrm{~Hz}, 1 \mathrm{H}), 3.51(\mathrm{dd}, J=9.9$, $7.5 \mathrm{~Hz}, 1 \mathrm{H}), 3.79(\mathrm{t}, J=6.3 \mathrm{~Hz}, 2 \mathrm{H}), 3.83-3.90(\mathrm{~m}, 1 \mathrm{H}), 3.94(\mathrm{~d}$, $J=2.1 \mathrm{~Hz}, 1 \mathrm{H}), 6.71(\mathrm{t}, J=7.3 \mathrm{~Hz}, 1 \mathrm{H}), 7.35-7.47(\mathrm{~m}, 6 \mathrm{H})$, $7.63-7.68(\mathrm{~m}, 4 \mathrm{H}) .{ }^{13} \mathrm{C} \mathrm{NMR}\left(75 \mathrm{MHz}, \mathrm{CDCl}_{3}\right) \delta-5.4\left(2 \mathrm{CH}_{3}\right)$, $11.2\left(\mathrm{CH}_{3}\right), 11.3\left(\mathrm{CH}_{3}\right), 11.9\left(\mathrm{CH}_{3}\right), 13.4\left(\mathrm{CH}_{3}\right), 18.3(\mathrm{C}), 19.2$ (C), $25.9\left(3 \mathrm{CH}_{3}\right), 26.8\left(3 \mathrm{CH}_{3}\right), 32.5\left(\mathrm{CH}_{2}\right), 37.9(\mathrm{CH}), 38.7(\mathrm{CH})$, $41.4(\mathrm{CH}), 59.8\left(\mathrm{CH}_{3}\right), 62.4\left(\mathrm{CH}_{2}\right), 66.4\left(\mathrm{CH}_{2}\right), 74.0(\mathrm{CH}), 83.9$ $(\mathrm{CH}), 127.7(4 \mathrm{CH}), 129.8(2 \mathrm{CH}), 133.5(2 \mathrm{C}), 135.5(4 \mathrm{CH}), 137.5$ (C), 138.6(CH), 205.9(C). HRMS (TOF MS ES ${ }^{+}$) $m / z$ Calcd for $\mathrm{C}_{38} \mathrm{H}_{62} \mathrm{O}_{5} \mathrm{Si}_{2}\left(\mathrm{M}+\mathrm{Na}^{+}\right): 677.4034$. Found: 677.4048. $[\alpha]_{\mathrm{D}}=$ $+2.0\left(c=2.4, \mathrm{CHCl}_{3}\right)$. IR (Film) $v 2955,2929,2857,2359,2341$, $1651,1471,1428,1091,701 \mathrm{~cm}^{-1}$.

To a cooled $\left(-78^{\circ} \mathrm{C}\right)$ solution of this $\beta$-keto alcohol $(715 \mathrm{mg}$, $1.10 \mathrm{mmol}, 1.0$ equiv.) in $\mathrm{CH}_{2} \mathrm{Cl}_{2}(20 \mathrm{~mL})$ was added dropwise $\mathrm{Zn}\left(\mathrm{BH}_{4}\right)_{2}\left(0.15 \mathrm{M}\right.$ solution in $\mathrm{Et}_{2} \mathrm{O}, 36.0 \mathrm{~mL}, 5.50 \mathrm{mmol}$, 5.0 equiv.). The mixture was stirred at $-60^{\circ} \mathrm{C}$ for $1 \mathrm{~h}$, then the temperature was allowed to warm to $-40{ }^{\circ} \mathrm{C}$. After $4 \mathrm{~h}$ at $-40{ }^{\circ} \mathrm{C}$, the reaction was quenched by addition of $\mathrm{MeOH}(5 \mathrm{~mL})$ at this temperature. The mixture was extracted with $\mathrm{CH}_{2} \mathrm{Cl}_{2}$ $(3 \times)$ and the combined organic layers were washed with a saturated aqueous solution of $\mathrm{NH}_{4} \mathrm{Cl}$, dried over $\mathrm{MgSO}_{4}$, and concentrated in vacuo. The residue was purified by chromatography on silica gel (cyclohexane/Et $\left.{ }_{2} \mathrm{O} 90: 10-50: 50\right)$ to afford diol 19a (655 mg, 91\% yield). ${ }^{1} \mathrm{H}$ NMR (300 $\left.\mathrm{MHz}, \mathrm{CDCl}_{3}\right) \delta$ $0.06(\mathrm{~s}, 6 \mathrm{H}), 0.75(\mathrm{~d}, J=6.8 \mathrm{~Hz}, 3 \mathrm{H}), 0.80(\mathrm{~d}, J=7.0 \mathrm{~Hz}, 3 \mathrm{H}), 0.83$ $(\mathrm{d}, J=6.9 \mathrm{~Hz}, 3 \mathrm{H}), 0.90(\mathrm{~s}, 9 \mathrm{H}), 1.04(\mathrm{~s}, 9 \mathrm{H}), 1.52(\mathrm{~s}, 3 \mathrm{H}), 1.72-$ $1.78(\mathrm{~m}, 1 \mathrm{H}), 1.80-1.92(\mathrm{~m}, 2 \mathrm{H}), 2.34(\mathrm{q}, J=7.0 \mathrm{~Hz}, 1 \mathrm{H}), 2.37$ $(\mathrm{q}, J=7.0 \mathrm{~Hz}, 1 \mathrm{H}), 3.38-3.52(\mathrm{~m}, 3 \mathrm{H}), 3.48(\mathrm{~s}, 3 \mathrm{H}), 3.68(\mathrm{t}, J=$ $7.0 \mathrm{~Hz}, 2 \mathrm{H}), 3.77$ (br d, $J=10.0 \mathrm{~Hz}, 1 \mathrm{H}), 4.16$ (br s, $1 \mathrm{H}), 4.20$ (br $\mathrm{s}, 1 \mathrm{H}), 4.74($ br s, $1 \mathrm{H}), 5.52(\mathrm{t}, J=7.0 \mathrm{~Hz}, 1 \mathrm{H}), 7.31-7.42(\mathrm{~m}$, $6 \mathrm{H}), 7.62-7.71(\mathrm{~m}, 4 \mathrm{H}) .{ }^{13} \mathrm{C} \mathrm{NMR}\left(75 \mathrm{MHz}, \mathrm{CDCl}_{3}\right) \delta-5.5$ $\left(\mathrm{CH}_{3}\right),-5.4\left(\mathrm{CH}_{3}\right), 4.2\left(\mathrm{CH}_{3}\right), 10.4\left(\mathrm{CH}_{3}\right), 13.6\left(2 \mathrm{CH}_{3}\right), 18.3(\mathrm{C})$, $19.2(\mathrm{C}), 25.9\left(3 \mathrm{CH}_{3}\right), 26.9\left(3 \mathrm{CH}_{3}\right), 31.4\left(\mathrm{CH}_{2}\right), 36.2(\mathrm{CH}), 38.3$ $(\mathrm{CH}), 38.6(\mathrm{CH}), 60.8\left(\mathrm{CH}_{3}\right), 63.7\left(\mathrm{CH}_{2}\right), 65.9\left(\mathrm{CH}_{2}\right), 79.8(\mathrm{CH})$, $80.4(\mathrm{CH}), 86.2(\mathrm{CH}), 120.3(\mathrm{CH}), 127.6(4 \mathrm{CH}), 129.5(2 \mathrm{CH})$, 134.1 (2C), 135.6 (4CH), 136.6 (C). HRMS (TOF MS ES ${ }^{+}$) $m / z$ Calcd for $\mathrm{C}_{38} \mathrm{H}_{64} \mathrm{O}_{5} \mathrm{Si}_{2}\left(\mathrm{M}+\mathrm{Na}^{+}\right): 679.4190$. Found: 679.4173 . $[\alpha]_{\mathrm{D}}=+1.4\left(c=0.2, \mathrm{CHCl}_{3}\right)$. IR (Film) $v 3445,2928,2857,1471$, $1427,1255,1111,1089,701 \mathrm{~cm}^{-1}$.

$(2 R, 3 S, 4 R, 5 R, 6 S, 7 R, E)-11$-(tert-Butyldiphenylsilyloxy)-3methoxy-2,4,6,8-tetramethyl-5,7-bis(triethylsilyloxy)undec-8enal 20a. Diol 19a (550 mg, $0.84 \mathrm{mmol}, 1.0$ equiv) was dissolved in THF $(20 \mathrm{~mL})$ at room temperature. Water $(10 \mathrm{~mL})$ followed by acetic acid $(30 \mathrm{~mL})$ were then added. The mixture was stirred at room temperature for $18 \mathrm{~h}$. The solution was diluted in $\mathrm{Et}_{2} \mathrm{O}$ and carefully washed with saturated aqueous solution of $\mathrm{NaH}$ $\mathrm{CO}_{3}(2 \times)$. The organic layer was dried over $\mathrm{MgSO}_{4}$ and the solvent was removed under reduced pressure. The residue was purified by chromatography on silica gel (cyclohexane/EtOAc 80:20-40:60) to give the wanted triol (400 mg, 88\% yield). ${ }^{1} \mathrm{H}$ $\operatorname{NMR}\left(300 \mathrm{MHz}, \mathrm{CDCl}_{3}\right) \delta 0.79(\mathrm{~d}, J=6.9 \mathrm{~Hz}, 3 \mathrm{H}), 0.80(\mathrm{~d}, J=$ $7.0 \mathrm{~Hz}, 3 \mathrm{H}), 0.91(\mathrm{~d}, J=7.0 \mathrm{~Hz}, 3 \mathrm{H}), 1.04(\mathrm{~s}, 9 \mathrm{H}), 1.52(\mathrm{~s}, 3 \mathrm{H})$, $1.71-1.81(\mathrm{~m}, 1 \mathrm{H}), 1.87-1.99(\mathrm{~m}, 2 \mathrm{H}), 2.29-2.40(\mathrm{~m}, 2 \mathrm{H}), 3.40$ $(\mathrm{dd}, J=6.9,3.0 \mathrm{~Hz}, 1 \mathrm{H}), 3.47(\mathrm{~s}, 3 \mathrm{H}), 3.53(\mathrm{dd}, J=10.5,8.1 \mathrm{~Hz}$, $1 \mathrm{H}), 3.62(\mathrm{dd}, J=10.5,5.1 \mathrm{~Hz}, 1 \mathrm{H}), 3.68(\mathrm{t}, J=6.8 \mathrm{~Hz}, 2 \mathrm{H}), 3.77$ $(\mathrm{dd}, J=9.5,1.7 \mathrm{~Hz}, 1 \mathrm{H}), 4.19($ br s, $1 \mathrm{H}), 5.50$ (t, $J=7.3 \mathrm{~Hz}, 1 \mathrm{H})$, $7.33-7.45(\mathrm{~m}, 6 \mathrm{H}), 7.64-7.71(\mathrm{~m}, 4 \mathrm{H}) .{ }^{13} \mathrm{C}$ NMR $(75 \mathrm{MHz}$, $\left.\mathrm{CDCl}_{3}\right) \delta 4.3\left(\mathrm{CH}_{3}\right), 11.4\left(\mathrm{CH}_{3}\right), 13.6\left(\mathrm{CH}_{3}\right), 14.0\left(\mathrm{CH}_{3}\right), 19.1(\mathrm{C})$, $26.8\left(3 \mathrm{CH}_{3}\right), 31.3\left(\mathrm{CH}_{2}\right), 36.1(\mathrm{CH}), 37.8(\mathrm{CH}), 38.2(\mathrm{CH})$, $60.4\left(\mathrm{CH}_{3}\right), 63.6\left(\mathrm{CH}_{2}\right), 66.2\left(\mathrm{CH}_{2}\right), 79.2(\mathrm{CH}), 80.6(\mathrm{CH})$, $86.5(\mathrm{CH}), 120.6(\mathrm{CH}), 127.6(4 \mathrm{CH}), 129.5(2 \mathrm{CH}), 134.0(2 \mathrm{C})$, $135.6(4 \mathrm{CH}), 136.7$ (C). HRMS (TOF MS ES $\left.{ }^{+}\right) \mathrm{m} / z$ Calcd for $\mathrm{C}_{32} \mathrm{H}_{50} \mathrm{O}_{5} \mathrm{Si}\left(\mathrm{M}+\mathrm{Na}^{+}\right)$: 565.3325. Found: 565.3334. $[\alpha]_{\mathrm{D}}=$ $+2.3\left(c=0.5, \mathrm{CHCl}_{3}\right)$. IR (Film) $v 3418,2932,1462,1427,1111$, $702 \mathrm{~cm}^{-1}$.

2,6-Lutidine (178 $\mu \mathrm{L}, 1.53 \mathrm{mmol}, 12.0$ equiv) and TESOTf (261 $\mu \mathrm{L}, 1.15 \mathrm{mmol}, 9.0$ equiv) were added to a solution of the 
previous triol (69 $\mathrm{mg}, 0.13 \mathrm{mmol}, 1.0$ equiv) in $\mathrm{CH}_{2} \mathrm{Cl}_{2}(4 \mathrm{~mL})$ at $0{ }^{\circ} \mathrm{C}$. The mixture was stirred at $0{ }^{\circ} \mathrm{C}$ for $45 \mathrm{~min}$ before being quenched by addition of a saturated aqueous solution of $\mathrm{NH}_{4} \mathrm{Cl}$. The mixture was then extracted with $\mathrm{CH}_{2} \mathrm{Cl}_{2}(3 \times)$. The combined organic layers were dried over $\mathrm{MgSO}_{4}$ and the solvent was removed in vacuo. The residue was purified by chromatography on silica gel (cyclohexane/EtOAc 100:0$80: 20)$ to afford the expected silyl ether $(111 \mathrm{mg}, 99 \%$ yield $)$ as a yellow oil. ${ }^{1} \mathrm{H}$ NMR $\left(300 \mathrm{MHz}, \mathrm{CDCl}_{3}\right) \delta 0.47-0.65(\mathrm{~m}, 18 \mathrm{H})$, $0.79(\mathrm{~d}, J=6.8 \mathrm{~Hz}, 3 \mathrm{H}), 0.83-1.03(\mathrm{~m}, 33 \mathrm{H}), 1.06(\mathrm{~s}, 9 \mathrm{H}), 1.49(\mathrm{~s}$, $3 \mathrm{H}), 1.75-1.85(\mathrm{~m}, 1 \mathrm{H}), 1.86-1.98(\mathrm{~m}, 2 \mathrm{H}), 2.20-2.40(\mathrm{~m}, 2 \mathrm{H})$, $3.30(\mathrm{~s}, 3 \mathrm{H}), 3.35(\mathrm{dd}, J=8.9,1.9 \mathrm{~Hz}, 1 \mathrm{H}), 3.46(\mathrm{dd}, J=9.6,6.7$ $\mathrm{Hz}, 1 \mathrm{H}), 3.56(\mathrm{dd}, J=9.6,8.0 \mathrm{~Hz}, 1 \mathrm{H}), 3.62-3.66(\mathrm{~m}, 1 \mathrm{H}), 3.66$ $(\mathrm{t}, J=7.5 \mathrm{~Hz}, 2 \mathrm{H}), 3.95(\mathrm{~d}, J=5.8 \mathrm{~Hz}, 1 \mathrm{H}), 5.40(\mathrm{t}, J=6.7 \mathrm{~Hz}$, 1H), 7.34-7.44 (m, 6H), 7.66-7.72 (m, 4H). ${ }^{13} \mathrm{C}$ NMR $(75$ $\left.\mathrm{MHz}, \mathrm{CDCl}_{3}\right) \delta 4.4\left(3 \mathrm{CH}_{2}\right), 5.0\left(3 \mathrm{CH}_{2}\right), 5.7\left(3 \mathrm{CH}_{2}\right), 6.8\left(3 \mathrm{CH}_{3}\right)$, $7.0\left(3 \mathrm{CH}_{3}\right), 7.2\left(3 \mathrm{CH}_{3}\right), 10.0\left(\mathrm{CH}_{3}\right), 10.9\left(\mathrm{CH}_{3}\right), 12.7\left(\mathrm{CH}_{3}\right), 15.4$ $\left(\mathrm{CH}_{3}\right), 19.1(\mathrm{C}), 26.8\left(3 \mathrm{CH}_{3}\right), 31.3\left(\mathrm{CH}_{2}\right), 38.3(\mathrm{CH}), 39.6(2 \mathrm{CH})$, $59.4\left(\mathrm{CH}_{3}\right), 63.5\left(\mathrm{CH}_{2}\right), 65.8\left(\mathrm{CH}_{2}\right), 76.4(\mathrm{CH}), 79.3(\mathrm{CH}), 81.0$ $(\mathrm{CH}), 121.9(\mathrm{CH}), 127.6(4 \mathrm{CH}), 129.5(2 \mathrm{CH}), 134.0(2 \mathrm{C}), 135.5$ (4CH), 138.7 (C). HRMS (TOF MS ES ${ }^{+}$) $\mathrm{m} / \mathrm{z}$ Calcd for $\mathrm{C}_{50} \mathrm{H}_{92} \mathrm{O}_{5} \mathrm{Si}_{4}\left(\mathrm{M}+\mathrm{Na}^{+}\right)$: 907.5920. Found: 907.5883 . $[\alpha]_{\mathrm{D}}=$ $-1.1\left(c=2.2, \mathrm{CHCl}_{3}\right)$. IR (Film) v 2956, 2876, 1459, 1427, 1239, $1094,1008,822,757,701 \mathrm{~cm}^{-1}$.

To a cooled $\left(-78^{\circ} \mathrm{C}\right)$ solution of oxalyl chloride $(49 \mu \mathrm{L}, 0.57$ mmol, 5.0 equiv) in $\mathrm{CH}_{2} \mathrm{Cl}_{2}(2 \mathrm{~mL})$ was added dropwise DMSO (87 $\mu \mathrm{L}, 1.13 \mathrm{mmol}, 10.0$ equiv). After $10 \mathrm{~min}$ at $-78^{\circ} \mathrm{C}$, a solution of the TES ether (100 $\mathrm{mg}, 0.11 \mathrm{mmol}, 1.0$ equiv) in $\mathrm{CH}_{2} \mathrm{Cl}_{2}(1 \mathrm{~mL})$ was slowly added. The mixture was stirred at $-78^{\circ} \mathrm{C}$ for $20 \mathrm{~min}$ and then at $-40{ }^{\circ} \mathrm{C}$ for $20 \mathrm{~min}$. At $-78^{\circ} \mathrm{C}$, triethylamine $(284 \mu \mathrm{L}, 2.03 \mathrm{mmol}, 18.0$ equiv) was added dropwise and the mixture was allowed to warm to room temperature over $2 \mathrm{~h}$. The resulting white and milky solution was diluted in $\mathrm{Et}_{2} \mathrm{O}$ and washed successively with a saturated aqueous solution of $\mathrm{NH}_{4} \mathrm{Cl}$ and water. The organic layer was dried over $\mathrm{MgSO}_{4}$ and the solvent was removed in vacuo. The crude aldehyde $\mathbf{2 0 a}(100 \mathrm{mg})$ was directly used in the next step without further purification. ${ }^{1} \mathrm{H}$ NMR $\left(300 \mathrm{MHz}, \mathrm{CDCl}_{3}\right)$ $\delta 0.48-0.66(\mathrm{~m}, 12 \mathrm{H}), 0.85-1.00(\mathrm{~m}, 24 \mathrm{H}), 1.05(\mathrm{~s}, 9 \mathrm{H}), 1.09(\mathrm{~d}$, $J=7.0 \mathrm{~Hz}, 3 \mathrm{H}), 1.48(\mathrm{~s}, 3 \mathrm{H}), 1.76-1.86(\mathrm{~m}, 1 \mathrm{H}), 1.89-2.01(\mathrm{~m}$, $1 \mathrm{H}), 2.20-2.35(\mathrm{~m}, 2 \mathrm{H}), 3.42-3.54(\mathrm{~m}, 1 \mathrm{H}), 3.07(\mathrm{~s}, 3 \mathrm{H}), 3.65(\mathrm{t}$, $J=7.5 \mathrm{~Hz}, 1 \mathrm{H}), 3.70-3.80(\mathrm{~m}, 3 \mathrm{H}), 3.89(\mathrm{~d}, J=7.2 \mathrm{~Hz}, 1 \mathrm{H}), 5.39$ $(\mathrm{t}, J=7.1 \mathrm{~Hz}, 1 \mathrm{H}), 7.33-7.44(\mathrm{~m}, 6 \mathrm{H}), 7.63-7.70(\mathrm{~m}, 4 \mathrm{H}), 9.80$ $(\mathrm{s}, 1 \mathrm{H}) .{ }^{13} \mathrm{C} \mathrm{NMR}\left(75 \mathrm{MHz}, \mathrm{CDCl}_{3}\right) \delta 5.0\left(3 \mathrm{CH}_{2}\right), 5.7\left(3 \mathrm{CH}_{2}\right)$, 6.6 $\left(\mathrm{CH}_{3}\right), 7.1\left(3 \mathrm{CH}_{3}\right), 7.2\left(3 \mathrm{CH}_{3}\right), 11.0\left(\mathrm{CH}_{3}\right), 12.0\left(\mathrm{CH}_{3}\right), 14.2$ $\left(\mathrm{CH}_{3}\right), 19.1(\mathrm{C}), 26.8\left(3 \mathrm{CH}_{3}\right), 31.3\left(\mathrm{CH}_{2}\right), 39.1(\mathrm{CH}), 40.4(\mathrm{CH})$, $49.0(\mathrm{CH}), 58.0\left(\mathrm{CH}_{3}\right), 63.4\left(\mathrm{CH}_{2}\right), 74.1(\mathrm{CH}), 80.0(\mathrm{CH}), 80.5$ $(\mathrm{CH}), 122.8(\mathrm{CH}), 127.6(4 \mathrm{CH}), 129.5(2 \mathrm{CH}), 133.9(2 \mathrm{C}), 135.5$ (4CH), $138.4(\mathrm{C}), 204.8(\mathrm{C})$

$(2 E, 4 E, 6 E, 8 S, 9 R, 10 S, 11 S, 12 S, 13 R, 14 E)$-11,13,17-Trihydroxy-9-methoxy-8,10,12,14-tetramethylheptadeca-2,4,6,14-tetraenoic Acid 1a. $n$-BuLi (1.6 M solution in hexanes, $622 \mu \mathrm{L}$, 0.99 mmol, 1.7 equiv) was added to a solution of diisopropylamine $\left(140 \mu \mathrm{L}, 0.99 \mathrm{mmol}, 1.7\right.$ equiv) in THF $(3 \mathrm{~mL})$ at $-78^{\circ} \mathrm{C}$. The resulting pale yellow solution was stirred at $-78^{\circ} \mathrm{C}$ for $5 \mathrm{~min}$ and then at $0{ }^{\circ} \mathrm{C}$ for $15 \mathrm{~min}$. A solution of phosphonate 2 (347 mg, $0.99 \mathrm{mmol}, 1.7$ equiv) in THF ( $5 \mathrm{~mL}$ ) was slowly added at $-78^{\circ} \mathrm{C}$. The resulting dark-brown solution was stirred for $15 \mathrm{~min}$ at $-78{ }^{\circ} \mathrm{C}$ before addition of aldehyde 20a $(450 \mathrm{mg}$, $0.58 \mathrm{mmol}, 1.0$ equiv) in THF $(5 \mathrm{~mL})$. The mixture was stirred for $15 \mathrm{~min}$ at $-78^{\circ} \mathrm{C}$ then $30 \mathrm{~min}$ at $0{ }^{\circ} \mathrm{C}$. The mixture was then extracted with $\mathrm{Et}_{2} \mathrm{O}(2 \times)$ and washed with a saturated aqueous solution of $\mathrm{NH}_{4} \mathrm{Cl}$. The combined organic layers were dried over $\mathrm{MgSO}_{4}$ and concentrated under reduced pressure. The residue was purified by chromatography on silica gel (cyclohexane/ $\mathrm{Et}_{2} \mathrm{O}$ 100:0-90:10) to afford the desired ester (330 mg, 59\% yield over two steps). ${ }^{1} \mathrm{H}$ NMR $\left(300 \mathrm{MHz}, \mathrm{CDCl}_{3}\right) \delta 0.05$ (s, $9 \mathrm{H}), 0.45-0.65(\mathrm{~m}, 12 \mathrm{H}), 0.85-0.95(\mathrm{~m}, 27 \mathrm{H}), 0.99-1.05(\mathrm{~m}$,
$2 \mathrm{H}), 1.06(\mathrm{~s}, 9 \mathrm{H}), 1.47(\mathrm{~s}, 3 \mathrm{H}), 1.80-1.95(\mathrm{~m}, 2 \mathrm{H}), 2.20-2.40(\mathrm{~m}$, $2 \mathrm{H}), 2.40-2.52(\mathrm{~m}, 1 \mathrm{H}), 3.03(\mathrm{dd}, J=7.0,3.7 \mathrm{~Hz}, 1 \mathrm{H}), 3.25(\mathrm{~s}$, $3 \mathrm{H}), 3.62-3.66(\mathrm{~m}, 1 \mathrm{H}), 3.66(\mathrm{t}, J=7.7 \mathrm{~Hz}, 2 \mathrm{H}), 3.86(\mathrm{~d}, J=$ $7.5 \mathrm{~Hz}, 1 \mathrm{H}), 4.20-4.27(\mathrm{~m}, 2 \mathrm{H}), 5.41(\mathrm{t}, J=6.4 \mathrm{~Hz}, 1 \mathrm{H}), 5.82(\mathrm{~d}$, $J=15.5 \mathrm{~Hz}, 1 \mathrm{H}), 5.94(\mathrm{dd}, J=15.1,7.3 \mathrm{~Hz}, 1 \mathrm{H}), 6.10(\mathrm{dd}, J=$ $15.1,10.2 \mathrm{~Hz}, 1 \mathrm{H}), 6.20(\mathrm{dd}, J=14.5,11.4 \mathrm{~Hz}, 1 \mathrm{H}), 6.50(\mathrm{dd}, J=$ $14.5,10.2 \mathrm{~Hz}, 1 \mathrm{H}), 7.28(\mathrm{dd}, J=15.5,11.4 \mathrm{~Hz}, 1 \mathrm{H}), 7.33-7.44$ $(\mathrm{m}, 6 \mathrm{H}), 7.65-7.71(\mathrm{~m}, 4 \mathrm{H}) .{ }^{13} \mathrm{C} \mathrm{NMR}\left(75 \mathrm{MHz}, \mathrm{CDCl}_{3}\right) \delta-1.5$ $\left(3 \mathrm{CH}_{3}\right), 5.0\left(3 \mathrm{CH}_{2}\right), 5.8\left(3 \mathrm{CH}_{2}\right), 6.9\left(3 \mathrm{CH}_{3}\right), 7.2\left(3 \mathrm{CH}_{3}\right), 10.9$ $\left(\mathrm{CH}_{3}\right), 12.4\left(\mathrm{CH}_{3}\right), 14.1\left(\mathrm{CH}_{3}\right), 15.2\left(\mathrm{CH}_{3}\right), 17.3\left(\mathrm{CH}_{2}\right), 19.1(\mathrm{C})$, $26.8\left(3 \mathrm{CH}_{3}\right), 31.3\left(\mathrm{CH}_{2}\right), 39.3(\mathrm{CH}), 39.4(\mathrm{CH}), 39.9(\mathrm{CH}), 59.6$ $\left(\mathrm{CH}_{3}\right), 62.4\left(\mathrm{CH}_{2}\right), 63.4\left(\mathrm{CH}_{2}\right), 76.8(\mathrm{CH}), 84.0(\mathrm{CH}), 87.6(\mathrm{CH})$, $120.5(\mathrm{CH}), 122.8(\mathrm{CH}), 127.6(4 \mathrm{CH}), 127.7(\mathrm{CH}), 128.7(\mathrm{CH})$, $129.6(2 \mathrm{CH}), 133.9(2 \mathrm{C}), 135.5(4 \mathrm{CH}), 138.6(\mathrm{C}), 140.9(\mathrm{CH})$, $144.3(\mathrm{CH}), 144.4(\mathrm{CH}), 167.3(\mathrm{C})$.

To a solution of this ester $(75 \mathrm{mg}, 0.08 \mathrm{mmol}, 1.0$ equiv) in dry $\mathrm{DMF}$ at $0{ }^{\circ} \mathrm{C}(0.7 \mathrm{~mL})$ was added a solution of TAS-F $(150 \mathrm{mg}$, $0.42 \mathrm{mmol}, 7.0$ equiv) in dry $\operatorname{DMF}(0.2 \mathrm{~mL})$. The resulting purple solution was stirred at $0{ }^{\circ} \mathrm{C}$ for $15 \mathrm{~min}$ then at room temperature for $9 \mathrm{~h}$. The mixture was then diluted with EtOAc and washed with an aqueous $\mathrm{pH} 2-3 \mathrm{HCl}$ solution. The aqueous layer was extracted with EtOAc $(2 \times)$ and the combined organic layers were washed $(4 \times)$ with small quantities of a saturated aqueous $\mathrm{NaCl}$ solution, dried over $\mathrm{MgSO}_{4}$, and concentrated in vacuo. The residue was purified by chromatography on silica gel (EtOAc/MeOH 100:0-80:20) to give title compound 1a (20 mg, 67\% yield). ${ }^{1} \mathrm{H}$ NMR (300 MHz, MeOD) $\delta 0.87(\mathrm{~d}, J=7.1 \mathrm{~Hz}, 3 \mathrm{H}), 0.97(\mathrm{~d}, J=6.8 \mathrm{~Hz}, 3 \mathrm{H}), 1.11(\mathrm{~d}, J=6.6$ $\mathrm{Hz}, 3 \mathrm{H}), 1.54(\mathrm{~s}, 3 \mathrm{H}), 1.73-1.83(\mathrm{~m}, 1 \mathrm{H}), 1.98-2.08(\mathrm{~m}, 1 \mathrm{H})$, $2.33(\mathrm{q}, J=6.7 \mathrm{~Hz}, 2 \mathrm{H}), 2.48-2.60(\mathrm{~m}, 1 \mathrm{H}), 3.30-3.34(\mathrm{~m}, 1 \mathrm{H})$, $3.41(\mathrm{~s}, 3 \mathrm{H}), 3.48(\mathrm{dd}, J=10.1,1.7 \mathrm{~Hz}, 1 \mathrm{H}), 3.66(\mathrm{t}, J=6.7 \mathrm{~Hz}$, $2 \mathrm{H}), 3.96(\mathrm{~d}, J=8.2 \mathrm{~Hz}, 1 \mathrm{H}), 5.50(\mathrm{t}, J=6.7 \mathrm{~Hz}, 1 \mathrm{H}), 5.90(\mathrm{~d}, J=$ $15.2 \mathrm{~Hz}, 1 \mathrm{H}), 5.95(\mathrm{dd}, J=15.3,9.2 \mathrm{~Hz}, 1 \mathrm{H}), 6.23(\mathrm{dd}, J=15.3$, $10.7 \mathrm{~Hz}, 1 \mathrm{H}), 6.37(\mathrm{dd}, J=14.8,11.3 \mathrm{~Hz}, 1 \mathrm{H}), 6.65(\mathrm{dd}, J=14.8$, $10.7 \mathrm{~Hz}, 1 \mathrm{H}), 7.36(\mathrm{dd}, J=15.2,11.3 \mathrm{~Hz}, 1 \mathrm{H}) .{ }^{13} \mathrm{C} \mathrm{NMR}$ (75 MHz, MeOD) $\delta 7.9\left(\mathrm{CH}_{3}\right), 11.9\left(\mathrm{CH}_{3}\right), 12.4\left(\mathrm{CH}_{3}\right), 18.1$ $\left(\mathrm{CH}_{3}\right), 32.4\left(\mathrm{CH}_{2}\right), 38.6(\mathrm{CH}), 40.3(\mathrm{CH}), 41.8(\mathrm{CH}), 59.1\left(\mathrm{CH}_{3}\right)$, $62.8\left(\mathrm{CH}_{2}\right), 74.5(\mathrm{CH}), 82.2(\mathrm{CH}), 87.3(\mathrm{CH}), 121.7(\mathrm{CH}), 125.6$ $(\mathrm{CH}), 129.7(\mathrm{CH}), 130.7(\mathrm{CH}), 139.0(\mathrm{C}), 142.9(\mathrm{CH}), 144.7$ (CH), $146.8(\mathrm{CH}), 170.8(\mathrm{C})$. HRMS (TOF MS ES ${ }^{+}$) $m / z$ Calcd for $\mathrm{C}_{22} \mathrm{H}_{36} \mathrm{O}_{6}\left(\mathrm{M}+\mathrm{Na}^{+}\right)$: 419.2404. Found: 419.2418. $[\alpha]_{\mathrm{D}}=$ $-2.5\left(c=0.3, \mathrm{CHCl}_{3}\right)$. IR (Film) v 3370, 2932, 1688, 1612, 1260, $1078,1007,702 \mathrm{~cm}^{-1}$

$(2 E, 4 E, 6 E, 8 R, 9 R, 10 S, 11 S, 12 S, 13 R, 14 E)-11,13,17-T r i h y-$ droxy-9-methoxy-8,10,12,14-tetramethylheptadeca-2,4,6,14-tetraenoic Acid 1b. ${ }^{1} \mathrm{H}$ NMR (300 MHz, MeOD) $\delta 0.79$ (d, $J=$ $7.1 \mathrm{~Hz}, 3 \mathrm{H}), 0.96(\mathrm{~d}, J=6.8 \mathrm{~Hz}, 3 \mathrm{H}), 1.15(\mathrm{~d}, J=6.9 \mathrm{~Hz}, 3 \mathrm{H}), 1.62$ $(\mathrm{s}, 3 \mathrm{H}), 1.75-1.87(\mathrm{~m}, 1 \mathrm{H}), 2.04-2.15(\mathrm{~m}, 1 \mathrm{H}), 2.38(\mathrm{q}, J=7.1$ $\mathrm{Hz}, 2 \mathrm{H}), 2.63-2.72(\mathrm{~m}, 1 \mathrm{H}), 3.39(\mathrm{dd}, J=5.4,3.2 \mathrm{~Hz}, 1 \mathrm{H}), 3.43$ $(\mathrm{s}, 3 \mathrm{H}), 3.54(\mathrm{dd}, J=10.0,1.6 \mathrm{~Hz}, 1 \mathrm{H}), 3.65(\mathrm{t}, J=7.1 \mathrm{~Hz}, 2 \mathrm{H})$, $4.02(\mathrm{~d}, J=8.1 \mathrm{~Hz}, 1 \mathrm{H}), 5.53(\mathrm{t}, J=7.1 \mathrm{~Hz}, 1 \mathrm{H}), 5.90(\mathrm{~d}, J=$ $14.9 \mathrm{~Hz}, 1 \mathrm{H}), 6.09(\mathrm{dd}, J=15.3,8.3 \mathrm{~Hz}, 1 \mathrm{H}), 6.18(\mathrm{dd}, J=15.3$, $9.6 \mathrm{~Hz}, 1 \mathrm{H}), 6.34(\mathrm{dd}, J=14.5,11.1 \mathrm{~Hz}, 1 \mathrm{H}), 6.64(\mathrm{dd}, J=14.5$, $9.6 \mathrm{~Hz}, 1 \mathrm{H}), 7.33(\mathrm{dd}, J=14.9,11.1 \mathrm{~Hz}, 1 \mathrm{H}) .{ }^{13} \mathrm{C} \mathrm{NMR}$ (75 MHz, MeOD) $\delta 7.9\left(\mathrm{CH}_{3}\right), 12.0\left(\mathrm{CH}_{3}\right), 12.8\left(\mathrm{CH}_{3}\right), 20.1$ $\left(\mathrm{CH}_{3}\right), 32.4\left(\mathrm{CH}_{2}\right), 38.5(\mathrm{CH}), 39.2(\mathrm{CH}), 40.8(\mathrm{CH}), 59.3\left(\mathrm{CH}_{3}\right)$, $62.8\left(\mathrm{CH}_{2}\right), 75.5(\mathrm{CH}), 81.9(\mathrm{CH}), 88.1(\mathrm{CH}), 121.4(\mathrm{CH}), 125.0$ $(\mathrm{CH}), 129.4(\mathrm{CH}), 130.7(\mathrm{CH}), 139.2(\mathrm{C}), 142.9(\mathrm{CH}), 144.6$ (CH), $146.9(\mathrm{CH}), 170.8(\mathrm{C})$. HRMS (TOF MS ES ${ }^{+}$) $m / z$ Calcd for $\mathrm{C}_{22} \mathrm{H}_{36} \mathrm{O}_{6}\left(\mathrm{M}+\mathrm{Na}^{+}\right): 419.2404$. Found: 419.2400. $[\alpha]_{\mathrm{D}}=$ $-28.3\left(c=0.6, \mathrm{CHCl}_{3}\right)$. IR (Film) $v 3368,2932,1688,1611,1260$, $1078,1007,702 \mathrm{~cm}^{-1}$

$(2 E, 4 E, 6 E, 8 S, 9 S, 10 S, 11 S, 12 S, 13 R, 14 E)-11,13,17-T r i h y d r-$ oxy-9-methoxy-8,10,12,14-tetramethylheptadeca-2,4,6,14-tetraenoic Acid 1c. ${ }^{1} \mathrm{H}$ NMR $(300 \mathrm{MHz}, \mathrm{MeOD}) \delta 0.80(\mathrm{~d}, J=7.0 \mathrm{~Hz}$, $3 \mathrm{H}), 0.94(\mathrm{~d}, J=6.8 \mathrm{~Hz}, 3 \mathrm{H}), 1.02(\mathrm{~d}, J=6.8 \mathrm{~Hz}, 3 \mathrm{H}), 1.64(\mathrm{~s}$, $3 \mathrm{H}), 1.72-1.82(\mathrm{~m}, 1 \mathrm{H}), 1.80-1.89(\mathrm{~m}, 1 \mathrm{H}), 2.34(\mathrm{q}, J=7.1 \mathrm{~Hz}$, $2 \mathrm{H}), 2.43-2.59(\mathrm{~m}, 1 \mathrm{H}), 3.41(\mathrm{~s}, 3 \mathrm{H}), 3.46(\mathrm{dd}, J=8.6,1.7 \mathrm{~Hz}$, 
$1 \mathrm{H}), 3.53(\mathrm{dd}, J=11.3,1.3 \mathrm{~Hz}, 1 \mathrm{H}), 3.61(\mathrm{t}, J=7.1 \mathrm{~Hz}, 2 \mathrm{H}), 4.04$ $(\mathrm{d}, J=7.7 \mathrm{~Hz}, 1 \mathrm{H}), 5.54(\mathrm{t}, J=7.1 \mathrm{~Hz}, 1 \mathrm{H}), 5.89(\mathrm{~d}, J=15.1 \mathrm{~Hz}$, $1 \mathrm{H}), 6.08$ (dd, $J=15.1,8.2 \mathrm{~Hz}, 1 \mathrm{H}), 6.28(\mathrm{dd}, J=15.1,10.4 \mathrm{~Hz}$, $1 \mathrm{H}), 6.37$ (dd, $J=14.8,11.3 \mathrm{~Hz}, 1 \mathrm{H}), 6.69(\mathrm{dd}, J=14.8,10.4 \mathrm{~Hz}$, $1 \mathrm{H}), 7.35(\mathrm{dd}, J=15.1,11.3 \mathrm{~Hz}, 1 \mathrm{H}) .{ }^{13} \mathrm{C} \mathrm{NMR}(75 \mathrm{MHz}$, MeOD) $\delta 7.4\left(\mathrm{CH}_{3}\right), 10.0\left(\mathrm{CH}_{3}\right), 12.1\left(\mathrm{CH}_{3}\right), 17.6\left(\mathrm{CH}_{3}\right), 32.3$ $\left(\mathrm{CH}_{2}\right), 38.1(\mathrm{CH}), 39.9(\mathrm{CH}), 42.5(\mathrm{CH}), 61.5\left(\mathrm{CH}_{3}\right), 62.8\left(\mathrm{CH}_{2}\right)$, $74.7(\mathrm{CH}), 82.2(\mathrm{CH}), 85.9(\mathrm{CH}), 121.4(\mathrm{CH}), 124.8(\mathrm{CH}), 129.6$ $(\mathrm{CH}), 131.0(\mathrm{CH}), 139.2(\mathrm{C}), 142.8(\mathrm{CH}), 145.1(\mathrm{CH}), 146.9$ (CH), 170.8 (C). HRMS (TOF MS ES ${ }^{+}$) $m / z$ Calcd for $\mathrm{C}_{22} \mathrm{H}_{36} \mathrm{O}_{6}\left(\mathrm{M}+\mathrm{Na}^{+}\right)$: 419.2404. Found: 419.2408. $[\alpha]_{\mathrm{D}}=$ $-13.5\left(c=0.4, \mathrm{CHCl}_{3}\right)$. IR (Film) $v$ 3370, 2932, 1688, 1612, $1260,1078,1007,702 \mathrm{~cm}^{-1}$.

$(2 E, 4 E, 6 E, 8 R, 9 S, 10 S, 11 S, 12 S, 13 R, 14 E)-11,13,17-T r i h y d r-$ oxy-9-methoxy-8,10,12,14-tetramethylheptadeca-2,4,6,14-tetraenoic Acid 1d. ${ }^{1} \mathrm{H}$ NMR (300 MHz, MeOD) $\delta 0.76(\mathrm{~d}, J=6.9 \mathrm{~Hz}$, $3 \mathrm{H}), 0.88(\mathrm{~d}, J=6.8 \mathrm{~Hz}, 3 \mathrm{H}), 1.17(\mathrm{~d}, J=6.6 \mathrm{~Hz}, 3 \mathrm{H}), 1.64(\mathrm{~s}$, $3 \mathrm{H}), 1.66-1.76(\mathrm{~m}, 1 \mathrm{H}), 1.76-1.86(\mathrm{~m}, 1 \mathrm{H}), 2.34(\mathrm{q}, J=7.1 \mathrm{~Hz}$, $2 \mathrm{H}), 2.45-2.61(\mathrm{~m}, 1 \mathrm{H}), 3.47(\mathrm{dd}, J=8.9,1.9 \mathrm{~Hz}, 1 \mathrm{H}), 3.50-3.52$ $(\mathrm{m}, 1 \mathrm{H}), 3.52(\mathrm{~s}, 3 \mathrm{H}), 3.61(\mathrm{t}, J=7.1 \mathrm{~Hz}, 2 \mathrm{H}), 4.03(\mathrm{~d}, J=7.7 \mathrm{~Hz}$, $1 \mathrm{H}), 5.54(\mathrm{t}, J=7.1 \mathrm{~Hz}, 1 \mathrm{H}), 5.86(\mathrm{dd}, J=15.2,9.3 \mathrm{~Hz}, 1 \mathrm{H}), 5.89$ $(\mathrm{d}, J=15.0 \mathrm{~Hz}, 1 \mathrm{H}), 6.25(\mathrm{dd}, J=15.2,10.6 \mathrm{~Hz}, 1 \mathrm{H}), 6.37(\mathrm{dd}, J=$ $14.9,11.2 \mathrm{~Hz}, 1 \mathrm{H}), 6.64(\mathrm{dd}, J=14.9,10.6 \mathrm{~Hz}, 1 \mathrm{H}), 7.33(\mathrm{dd}, J=$ 15.0, 11.2 Hz, 1H). ${ }^{13} \mathrm{C}$ NMR (75 MHz, MeOD) $\delta 7.4\left(\mathrm{CH}_{3}\right), 9.9$ $\left(\mathrm{CH}_{3}\right), 12.1\left(\mathrm{CH}_{3}\right), 18.7\left(\mathrm{CH}_{3}\right), 32.3\left(\mathrm{CH}_{2}\right), 38.1(\mathrm{CH}), 40.6$ $(\mathrm{CH}), 42.9(\mathrm{CH}), 61.8\left(\mathrm{CH}_{3}\right), 62.8\left(\mathrm{CH}_{2}\right), 74.8(\mathrm{CH}), 82.3(\mathrm{CH})$, $85.6(\mathrm{CH}), 121.6(\mathrm{CH}), 124.8(\mathrm{CH}), 129.8(\mathrm{CH}), 130.9(\mathrm{CH})$, $139.2(\mathrm{C}), 142.6(\mathrm{CH}), 143.7(\mathrm{CH}), 146.8(\mathrm{CH}), 170.8(\mathrm{C})$. HRMS (TOF MS ES $\left.{ }^{+}\right) m / z$ Calcd for $\mathrm{C}_{22} \mathrm{H}_{36} \mathrm{O}_{6}\left(\mathrm{M}+\mathrm{Na}^{+}\right)$: 419.2404. Found: 419.2415. $[\alpha]_{\mathrm{D}}=+8.4\left(c=0.5, \mathrm{CHCl}_{3}\right)$. IR (Film) $v$ 3397, 2933, 1689, 1614, 1261, 1078, 1007, $705 \mathrm{~cm}^{-1}$.

$(2 E, 4 E, 6 E, 8 S, 9 R, 10 S, 11 R, 12 R, 13 S, 14 E)-11,13,17-T r i h y d r-$ oxy-9-methoxy-8,10,12,14-tetramethylheptadeca-2,4,6,14-tetraenoic Acid 1e. ${ }^{1} \mathrm{H}$ NMR (300 MHz, MeOD) $\delta 0.94(\mathrm{~d}, J=6.9 \mathrm{~Hz}$, $3 \mathrm{H}), 0.99(\mathrm{~d}, J=7.1 \mathrm{~Hz}, 3 \mathrm{H}), 1.11(\mathrm{~d}, J=6.8 \mathrm{~Hz}, 3 \mathrm{H}), 1.63(\mathrm{~s}$, $3 \mathrm{H}), 1.73-1.84(\mathrm{~m}, 1 \mathrm{H}), 1.95-2.04(\mathrm{~m}, 1 \mathrm{H}), 2.35(\mathrm{q}, J=7.1 \mathrm{~Hz}$, $2 \mathrm{H}), 2.53-2.66(\mathrm{~m}, 1 \mathrm{H}), 3.20(\mathrm{dd}, J=6.2,5.1 \mathrm{~Hz}, 1 \mathrm{H}), 3.47(\mathrm{~s}$, $3 \mathrm{H}), 3.61(\mathrm{t}, J=7.1 \mathrm{~Hz}, 2 \mathrm{H}), 3.85(\mathrm{dd}, J=6.7,3.5 \mathrm{~Hz}, 1 \mathrm{H}), 4.02$ $(\mathrm{d}, J=3.6 \mathrm{~Hz}, 1 \mathrm{H}), 5.53(\mathrm{t}, J=7.1 \mathrm{~Hz}, 1 \mathrm{H}), 5.89$ (d, $J=15.1 \mathrm{~Hz}$,
1H), $6.07(\mathrm{dd}, J=15.2,7.9 \mathrm{~Hz}, 1 \mathrm{H}), 6.29(\mathrm{dd}, J=15.2,10.4 \mathrm{~Hz}$, $1 \mathrm{H}), 6.39$ (dd, $J=14.7,11.2 \mathrm{~Hz}, 1 \mathrm{H}), 6.68(\mathrm{dd}, J=14.7,10.4 \mathrm{~Hz}$, $1 \mathrm{H}), 7.34(\mathrm{dd}, J=15.1,11.2 \mathrm{~Hz}, 1 \mathrm{H}) .{ }^{13} \mathrm{C} \mathrm{NMR}(75 \mathrm{MHz}$, MeOD) $\delta 9.5\left(\mathrm{CH}_{3}\right), 11.7\left(\mathrm{CH}_{3}\right), 13.9\left(\mathrm{CH}_{3}\right), 14.9\left(\mathrm{CH}_{3}\right), 32.3$ $\left(\mathrm{CH}_{2}\right), 39.1(\mathrm{CH}), 39.9(\mathrm{CH}), 40.9(\mathrm{CH}), 61.4\left(\mathrm{CH}_{3}\right), 62.9\left(\mathrm{CH}_{2}\right)$, $73.9(\mathrm{CH}), 78.0(\mathrm{CH}), 89.3(\mathrm{CH}), 121.7(\mathrm{CH}), 122.2(\mathrm{CH}), 129.9$ $(\mathrm{CH}), 130.7(\mathrm{CH}), 139.4(\mathrm{C}), 142.7(\mathrm{CH}), 144.9(\mathrm{CH}), 146.7$ (CH), 170.9 (C). HRMS (TOF MS $\mathrm{ES}^{+}$) $\mathrm{m} / \mathrm{z}$ Calcd for $\mathrm{C}_{22} \mathrm{H}_{36} \mathrm{O}_{6}\left(\mathrm{M}+\mathrm{Na}^{+}\right)$: 419.2404. Found: 419.2420. $[\alpha]_{\mathrm{D}}=$ $+10.0\left(c=0.6, \mathrm{CHCl}_{3}\right)$. IR (Film) v 3391, 2933, 1688, 1614, $1261,1078,1007 \mathrm{~cm}^{-1}$.

$(2 E, 4 E, 6 E, 8 R, 9 R, 10 S, 11 R, 12 R, 13 S, 14 E)-11,13,17-T r i h y d r-$ oxy-9-methoxy-8,10,12,14-tetramethylheptadeca-2,4,6,14-tetraenoic Acid 1f. ${ }^{1} \mathrm{H}$ NMR (300 MHz, MeOD) $\delta 0.93(\mathrm{~d}, J=6.8 \mathrm{~Hz}$, $3 \mathrm{H}), 0.95(\mathrm{~d}, J=6.8 \mathrm{~Hz}, 3 \mathrm{H}), 1.18(\mathrm{~d}, J=6.9 \mathrm{~Hz}, 3 \mathrm{H}), 1.62(\mathrm{~s}$, $3 \mathrm{H}), 1.70-1.80(\mathrm{~m}, 1 \mathrm{H}), 1.89-1.97(\mathrm{~m}, 1 \mathrm{H}), 2.35(\mathrm{q}, J=7.0 \mathrm{~Hz}$, $2 \mathrm{H}), 2.52-2.64(\mathrm{~m}, 1 \mathrm{H}), 3.19(\mathrm{dd}, J=7.3,3.3 \mathrm{~Hz}, 1 \mathrm{H}), 3.52(\mathrm{~s}$, $3 \mathrm{H}), 3.61(\mathrm{t}, J=7.0 \mathrm{~Hz}, 2 \mathrm{H}), 3.82(\mathrm{dd}, J=7.1,3.2 \mathrm{~Hz}, 1 \mathrm{H}), 4.01$ $(\mathrm{d}, J=4.4 \mathrm{~Hz}, 1 \mathrm{H}), 5.51(\mathrm{t}, J=7.0 \mathrm{~Hz}, 1 \mathrm{H}), 5.88(\mathrm{~d}, J=15.4 \mathrm{~Hz}$, $1 \mathrm{H}), 6.06(\mathrm{dd}, J=15.2,8.6 \mathrm{~Hz}, 1 \mathrm{H}), 6.25(\mathrm{dd}, J=15.2,10.4 \mathrm{~Hz}$, $1 \mathrm{H}), 6.35(\mathrm{dd}, J=14.7,11.3 \mathrm{~Hz}, 1 \mathrm{H}), 6.65(\mathrm{dd}, J=14.7,10.4 \mathrm{~Hz}$, $1 \mathrm{H}), 7.33(\mathrm{dd}, J=15.4,11.3 \mathrm{~Hz}, 1 \mathrm{H}) .{ }^{13} \mathrm{C} \operatorname{NMR}(75 \mathrm{MHz}$, MeOD) $\delta 9.7\left(\mathrm{CH}_{3}\right), 10.6\left(\mathrm{CH}_{3}\right), 10.9\left(\mathrm{CH}_{3}\right), 13.6\left(\mathrm{CH}_{3}\right), 32.1$ $\left(\mathrm{CH}_{2}\right), 39.2(\mathrm{CH}), 39.8(\mathrm{CH}), 41.2(\mathrm{CH}), 61.3\left(\mathrm{CH}_{3}\right), 62.8\left(\mathrm{CH}_{2}\right)$, $73.6(\mathrm{CH}), 77.7(\mathrm{CH}), 89.1(\mathrm{CH}), 122.0(\mathrm{CH}), 122.1(\mathrm{CH}), 129.5$ $(\mathrm{CH}), 131.2(\mathrm{CH}), 139.3(\mathrm{C}), 142.4(\mathrm{CH}), 143.0(\mathrm{CH}), 146.3$ (CH), 171.1 (C). HRMS (TOF MS ES ${ }^{+}$m/z Calcd for $\mathrm{C}_{22} \mathrm{H}_{36} \mathrm{O}_{6}\left(\mathrm{M}+\mathrm{Na}^{+}\right): 419.2404$. Found: 419.2416. $[\alpha]_{\mathrm{D}}=$ $+2.1\left(c=0.1, \mathrm{CHCl}_{3}\right)$. IR (Film) v 3391, 2933, 1688, 1614, $1261,1078,1007 \mathrm{~cm}^{-1}$.

Acknowledgment. We thank Pierre Fabre Laboratories and CNRS for a doctoral fellowship for E.F.

Supporting Information Available: Full data analysis of ${ }^{13} \mathrm{C}$ and ${ }^{1} \mathrm{H}$ NMR values for all examples. This material is available free of charge via the Internet 